\title{
Aromatisation of steroids in the bivalve Mytilus trossulus
}

\author{
Anna Hallmann ${ }^{1}$, Lucyna Konieczna ${ }^{2}$, Justyna Swiezak $^{3}$, Ryszard Milczarek ${ }^{1}$, Katarzyna Smolarz ${ }^{\text {Corresp. } 3}$ \\ 1 Department of Pharmaceutical Biochemistry, Medical University of Gdańsk, Gdańsk, Poland \\ 2 Department of Pharmaceutical Chemistry, Medical University of Gdańsk, Gdańsk, Poland \\ 3 Department of Marine Ecosystem Functioning, University of Gdańsk, Gdynia, Poland \\ Corresponding Author: Katarzyna Smolarz \\ Email address: oceksm@univ.gda.pl
}

In this study, we demonstrated the presence of the enzymatic complex able to perform aromatization (estrogen synthesis) in both, the microsomal and mitochondrial fractions of gills and gonads from Mytilus trossulus. Based on in vitro experiments, we highlighted the importance of temperature as the limiting factor of aromatisation efficiency $(A E)$ in mussels. After testing range of temperatures $\left(4^{\circ} \mathrm{C}-23^{\circ} \mathrm{C}\right)$, the highest $\mathrm{AE}$ was found during incubation at $8^{\circ} \mathrm{C}$ and $\mathrm{pH} 7.6(41.66 \mathrm{pmol} / \mathrm{h} / \mathrm{mg}$ protein in gills and $58.37 \mathrm{pmol} / \mathrm{h} / \mathrm{mg}$ protein in gonads). The results were confirmed during field studies where the most efficient aromatisation occurred in bivalves collected in spring while the least effective in those collected in winter. During in vitro studies, AE turned out to be more intensive in female gonads than in male gonads. The process was also more intensive in mitochondrial fraction than in microsomal one $(62.97 \mathrm{pmol} / \mathrm{h} / \mathrm{mg}$ protein in male gills and 73.94 $\mathrm{pmol} / \mathrm{h} / \mathrm{mg}$ protein in female gonads). Enzymatic complex (aromatase-like enzyme) catalysing aromatisation in mussels was found to be insensitive to inhibitory effect of selective inhibitors of mammalian aromatase such as letrozole and anastrazole, suggesting its different structure from vertebrate aromatase. Further in vivo studies using ${ }^{13} \mathrm{C}$-labelled steroids at $8^{\circ} \mathrm{C}$ temperature window confirmed that bivalves are able to uptake testosterone and androstenedione from the ambient environment and metabolise them to estrone and $17 \beta$-estradiol thus confirming endogenous estrogen' synthesis. 


\section{Aromatisation of steroids in the bivalve Mytilus trossulus}

Anna Hallmann ${ }^{1}$, Lucyna Konieczna ${ }^{2}$, Justyna Swiezak ${ }^{3}$, Ryszard Milczarek ${ }^{1}$, Katarzyna $\underline{\text { Smolarz }}$

${ }^{1}$ Department of Pharmaceutical Biochemistry, Medical University of Gdańsk, Poland

2 Department of Pharmaceutical Chemistry, Medical University of Gdańsk, Poland

${ }^{3}$ Department of Marine Ecosystem Functioning, University of Gdańsk, Poland

\section{Abstract}

In this study, we demonstrated the presence of the enzymatic complex able to perform aromatization (estrogen synthesis) in both, the microsomal and mitochondrial fractions of gills and gonads from Mytilus trossulus. Based on in vitro experiments, we highlighted the importance of temperature as the limiting factor of aromatisation efficiency (AE) in mussels. After testing range of temperatures $\left(4^{\circ} \mathrm{C}-23^{\circ} \mathrm{C}\right)$, the highest $A E$ was found during incubation at $8^{\circ} \mathrm{C}$ and $\mathrm{pH} 7.6$ (41.66 pmol/h/mg protein in gills and 58.37 $\mathrm{pmol} / \mathrm{h} / \mathrm{mg}$ protein in gonads). The results were confirmed during field studies where the most efficient aromatisation occurred in bivalves collected in spring while the least effective in those collected in winter. During in vitro studies, AE turned out to be more intensive in female gonads than in male gonads. The process was also more efficient in mitochondrial fraction than in microsomal one $(62.97 \mathrm{pmol} / \mathrm{h} / \mathrm{mg}$ protein in male gills and $73.94 \mathrm{pmol} / \mathrm{h} / \mathrm{mg}$ protein in female gonads). Enzymatic complex (aromatase-like enzyme) catalysing aromatisation in mussels was found to be insensitive to inhibitory effect of selective inhibitors of mammalian aromatase such as letrozole and anastrazole, suggesting its different structure from vertebrate aromatase. Further in vivo studies using ${ }^{13} \mathrm{C}$-labelled steroids at $8^{\circ} \mathrm{C}$ temperature window confirmed that bivalves are able to uptake testosterone and androstenedione from the ambient environment and metabolise them to estrone and $17 \beta$-estradiol thus confirming endogenous estrogen' synthesis.

\section{Introduction}

Since the presence of various sex steroids has long been confirmed in many species of marine bivalves, the two main questions in bivalves endocrinology are related to i) the role of steroids and ii) their origin in these organisms. Indeed, some studies provide 
evidence that sex steroids serve various physiological functions in bivalve tissues. For example, fluctuations of $17 \beta$-estradiol (E2) and testosterone (T) levels in Sinonovacula constricta were related to the reproductive cycle of the clams indicating their possible role as endogenous modulators of the gametogenetic cycle (Yan et al., 2011). In a study of Mezghani-Chaari et al. (Mezghani-Chaari et al., 2017) an exposure of Ruditapes decussatus to high $17 \beta$-estradiol doses resulted in sex-specific disorders in gametogenesis. In Li et al. (Li et al., 1998) Crassostrea gigas was exposed to E2 which promoted vitellin formation in the ovarian tissue. In Mytilus edulis an exposure to 17ßestradiol induced various alterations in the mRNA expression of monoamine serotonin receptor and cyclooxygenase that correlated with the bivalves' reproductive stage (Cubero-Leon et al., 2010). Yet, comparable exposure of $M$. edulis to E2 led to increased tissue concentrations of free and total estradiol, but induction of VTG or estrogen receptor (ER) gene expression in gonads was not confirmed (Puinean et al., 2006). Similarly, in other studies no or very little endocrine-related reproductive effect was identified (Ketata et al., 2008; Markov et al., 2009; Morthorst et al., 2014). Hence, Scott (Scott, 2013) in a critical review concluded that there is no indisputable bioassay evidence that vertebrate sex steroids have endocrinological or reproductive roles in molluscs. In spite of that, an association between gametogenesis stage and steroid content was reported with maximal steroids concentration often observed during reproduction peak and minimal concentration during low stage of gametogenesis (Jianbin, 2013; Wang \& Croll, 2007; Liu, Li \& Kong, 2008; Ciocan et al., 2010; Morthorst et al., 2014; Hallmann et al., 2016). In M. trossulus from the Gulf of Gdańsk (Baltic Sea, Poland), seasonal differences in E2 and T concentrations in gonads and gills were also found, but no direct relation between steroids level and stage of gonad development was confirmed (Zabrzańska et al., 2015; Hallmann et al., 2016; Smolarz et al., 2018). Instead, a strong correlation between water temperature and steroids level was observed (Smolarz et al., 2018) suggesting temperature as an important factor influencing tissue steroids content.

With regards to steroids such as estrogens, neither their origin nor their role in bivalves has been confirmed because steroidogenesis is not yet indubitably documented in this group of organisms. Known similarities in functioning of endocrine system in vertebrates and invertebrates include various signals of transduction to appropriate target sites for regulating gene expression (Janer et al., 2005). In higher organisms, the cytochrome P450 aromatase (CYP19) - a member of a large superfamily of cytochrome P450 enzymes - is involved in steroid biosynthesis and is expressed in estrogen-producing cells (Hall, 1985). Aromatase is responsible for the conversion of the androgens; androstenedione and testosterone into the estrogens: estrone and 17ß-estradiol, respectively (Thompson \& Siiteri, 1974; Kellis \& Vickery, 1987; Yoshida \& Osawa, 1991). Aromatization of androgens to estrogen occurs after multiple oxygenation processes, loss of the methyl group at C-19 and the elimination of the $1 \beta$ hydrogen 
(Numazawa, Yoshimura \& Oshibe, 1998). During aromatization, three moles of oxygen and three moles of NADPH for every mole of metabolized steroid substrate are used, resulting in three $\mathrm{H}_{2} \mathrm{O}$ molecules (Osawa et al.,1987). In vertebrates, aromatase is mainly present in the microsomal fraction (Simpson et al., 2002). However, earlier studies report that this enzyme can also be found in the mitochondria of human placenta (Finkelstein et al., 1985; Meigs \& Moorthy, 1984). Aromatase activity level in fish equals to $16 \mathrm{pmol} / \mathrm{h} / \mathrm{mg}$ protein (Orlando, Davis \& Guillette, 2002), in birds equals to $50 \mathrm{pmol} / \mathrm{h} / \mathrm{mg}$ protein (Foidart et al., 1998) and in human placenta $95 \mathrm{pmol} / \mathrm{min} / \mathrm{mg}$ protein (Milczarek et al., 2008).

Despite determination of androgens and estrogens in bivalve tissues, the occurrence of aromatization in this group of organisms is still unclear since most studies suggest that aromatase activity is either absent or at a very low level (Scott, 2012). In marine invertebrates, determination of aromatase activity is based on methods such as ELISA test, in which the content of final product is measured (Tinwell et al., 2011). This approach, however, lacks specificity since the reaction can be catalysed by aromatase as well as by other unidentified enzymes belonging to cytochrome P450 superfamily. Hence, the usage of antibodies against mammalian CYP19 in immunohistological staining in scattered single bivalve cells may spot non-specific cross-reactivity. Commercially available kits such as aromatase (CYP19A) Activity Assay Kit (Fluorometric, BioVision) seem to be suitable when applied to human tissue only, as they contain specific inhibitors of human aromatase that may not inhibit the reaction in bivalves. However, a method allowing to measure aromatization efficiency (AE) was described by Lavado et al. (Lavado, Janer \& Porte, 2006). It uses isotope-labelled substrate utilized by the $1 \beta-{ }^{3} \mathrm{H}$ androstenedione. In the presence of aromatase, a quantified amount of ${ }^{3} \mathrm{H}_{2} \mathrm{O}$ is produced from isotope-labelled substrate allowing for quantification of aromatization. Also here, non-specific cross-reactivity cannot be excluded since the reaction can be catalysed by aromatase as well as by a random enzyme belonging to the group of the cytochrome P450 family that contributes to oxygenations and loss of the methyl group at C-19 position. Aromatase (or aromataselike) activity measured using isotopic method in Crassostrea gigas was as low as 6 $\mathrm{fmol} / \mathrm{h} / \mathrm{gram}$ of wet weight (Le Curieux-Belfond et al., 2001) and therefore close to the measurability threshold. AE measured in gonads and digestive gland of $M$. edulis was also low $(1 \mathrm{pmol} / \mathrm{h} / \mathrm{mg}$ and $3 \mathrm{pmol} / \mathrm{h} / \mathrm{mg}$ of protein at maximum, respectively) (Lavado, Janer \& Porte, 2006). In addition, aromatase (CYP19) gene orthologue first appeared in a direct ancestor of the chordates - amphibians and there is no information about CYP19 gene in invertebrates available (Callard et al., 2011). Hence, Scott (Scott, 2012) in a critical appraisal gave a strong reasoning against the hypothesis of endogenous steroid origin in molluscs. Nevertheless, comparative phylogenetic analyses suggest the presence of aromatase gene also in lower organisms (Castro, Santos \& ReisHenriques, 2005). 
115 Since vertebrate aromatase is very sensitive to the inhibitory effects of certain drugs 116 such as letrozole, anastrozole and ketoconazole, one way of comparing the similarity of 117 an enzyme catalysing aromatization in various species to vertebrate aromatase is by 118 using targeting selectivity of known aromatase inhibitors. Letrozole inhibits aromatase

which is a subunit of the aromatase enzyme complex (Haynes et al., 2003; Bhatnagar, 2007). Anastrozole, by competitive inhibition achieved by direct and reversible bond to aromatase, blocks the conversion of androgens to estrogens (Hortobagyi \& Buzdar, 1998). Ketoconazole, characterized by the widest work spectrum, is commonly used as a synthetic antifungal pharmaceutical. It inhibits in a dose-dependent matter ovarian $3 \beta-$ hydroxysteroid dehydrogenase and 17-hydroxylase, essential enzymes for the formation of C-19 steroids (Nagai et al., 1986). It is also used as an irreversible steroidal aromatase inhibitor in pharmacotherapy. Ketoconazole also inhibits cholesterol side chain cleavage enzymes in the adrenal and testis, thus affecting androgen biosynthesis (Nagai et al., 1986; DiMattina et al., 1988).

The $M$. edulis complex belongs to strictly gonochorous species reaching sexual maturity at the age of one year with typical sex ratio around one (Kautsky, 1982; Newell et al., 1982). The reproduction of the blue mussel from the Baltic Sea, like many other temperate species, follows a seasonal pattern since it is correlated with temperature and food availability (Kautsky, 1982; Kautsky \& Evans, 1987). Early phase of gametogenesis occurs in late winter and/or early spring and the main spawning event takes place between May and July, but a second spawning peak can also be observed in autumn. To our knowledge, there is no data confirming the presence of hormone receptors initiating multiple signalling pathways and ultimately leading to sex determination and/or gametogenesis in bivalves. There is, however, a confirmed relationship between ambient water temperature and steroid content in $M$. trossulus (Smolarz et al., 2018). Additionally, the blue mussels are characterized by double uniparental inheritance (DUI) in which females inherit maternal mitochondria only while males inherit maternal and paternal ones. Since in pair mating this mtDNA biparental inheritance was associated with strong sex ratio bias, a relationship between DUI and sex determination in genus Mytilus was proposed by Passamonti et al. (Passamonti \& Ghiselli, 2009) and Zouros et al. (Zouros et al., 1994). Still little is known about interactions between reproduction pattern, sex determination and steroids in bivalves, hence a regulative role of estrogens in DUI-related sex determination cannot be excluded.

The main purpose of this study was therefore to confirm the occurrence of endogenous synthesis of steroids in marine bivalves by addressing aromatization in in vitro and in vivo studies using $M$. trossulus as a model species. In particular, we aimed at analysing i) the effect of temperature (season) and $\mathrm{pH}$ on the effectiveness of aromatization; ii) $\mathrm{AE}$ 
154 in microsomal and mitochondrial fractions of gills and gonads; iii) similarity of an

155

156

157

158

159

160

161

162

163

164

165

166

167

168

169

170

171

172

173

174

175

176

177

178

179

180

181

182

183

184

185

186

187

188

189 enzyme catalysing aromatization in bivalves to mammalian aromatase using targeting selectivity of known aromatase inhibitors and iv) sex- and tissue- related differences in aromatization efficiency.

\section{Material and methods}

\subsection{Chemicals and reagents}

Dexamethasone (internal standard), 4-Androstene-3,17-dione-2,3,4- ${ }^{13} \mathrm{C}_{3}$, Estrone-2,3,4${ }^{13} \mathrm{C}_{3}, 17 \beta$-Estradiol-2,3,4-13 $\mathrm{C}_{3}$, Testosterone-2,3,4-13 $\mathrm{C}_{3}$, Anastrozole, Letrozole, Ketoconazole, protease from Bacillus licheniformis (subtilisin), formic acid, acetone, methanol, acetonitrile, hexane, methylene chloride, charcoal activated, Tris, $\mathrm{HCl}$, $\mathrm{KH}_{2} \mathrm{PO}_{4}, \mathrm{~K}_{2} \mathrm{HPO}_{4}, \mathrm{KCl}, \mathrm{NADPH}$, glycerol, BSA, scintillation cocktail and Supel ${ }^{\mathrm{TM}}$-Select SPE HLB ( $6 \mathrm{~mL}, 200 \mathrm{mg}$ ) columns were provided by Sigma-Aldrich (St. Louis, MO, USA). $1 \beta-{ }^{3} \mathrm{H}$ Androstene-3,17-dione (30 Ci/mmol) was obtained from Perkin-Elmer Life Science (Boston, MA, USA).

\subsection{Sampling and tissue preparation}

The blue mussels Mytilus trossulus were collected by dredging from a sampling station located on the coastline of the Gulf of Gdańsk, Poland (N: 54 40' 00" E: $18^{\circ} 33^{\prime} 55^{\prime \prime}$ ) at $10.0 \mathrm{~m}$ depth. The shell length of collected individuals varied from $25 \mathrm{~mm}$ to $30 \mathrm{~mm}$ which corresponded to an age range of 3 to 4 years and indicated their sexual maturity. Next, mussels were transported to the laboratory and kept in aerated aquaria in conditions resembling natural when sampled (temperature and salinity).

In vitro analyses were performed on organisms collected in the period from 2012 to 2018. After dissection, gills and gonads were separated and mitochondria and microsomes were isolated, frozen and kept in $-80^{\circ} \mathrm{C}$ until the analysis. The analyses of temperature- and $\mathrm{pH}$ - related changes in $\mathrm{AE}$ in bivalve tissues were performed between 2012 and 2014 on 150 individuals. Seasonal analyses of AE were performed on approx. 400 blue mussels sampled in May 2012, July 2012, November 2012 and February 2013 (approx. 100 mussels analysed per season). In March 2015, the effect of aromatase inhibitors was studied on 100 organisms. Sex- and tissue- related differences in AE were performed on 100 organisms sampled in April 2016. Sexing was based on a small subsample of gonadal tissue placed on the microscope slide with saline solution and covered by cover slides. Prepared smears were analysed under light microscopy for the presence of ovaries (oocytes) or testis (spermatocytes) and classified accordingly as females or males. In vivo analyses were performed on individuals collected in April 2018. Exposure to ${ }^{13} \mathrm{C}_{3}$-labelled steroid mixture of blue mussels was performed without (in the first experiment) and with (in the second experiment) sexing after which bivalves

Peer) reviewing PDF | (2019:02:35004:1:1:NEW 26 Mar 2019) 
190

191

192

193

194

195

196

197

198

199

200

201

202

203

204

205

206

207

208

209

210

211

212

213

214

215

216

217

218

219

220

221

222

223

224

225

were dissected and the whole soft tissue was frozen in liquid nitrogen and stored at $80^{\circ} \mathrm{C}$.

2.3. Temperature, $\mathrm{pH}$, seasonal, sex and tissue - related aromatisation efficiency based on in vitro experiments

2.3.1. Preparation of gills and gonadal mitochondrial and microsomal fraction

Gonadal and gill tissues were pooled separately in order to obtain $25 \mathrm{ml}$ of each tissue volume. The tissue was manually homogenized in a glass Potter-Elvehjem

homogenizer with Teflon pestle in ice-cold $100 \mathrm{mM} \mathrm{KH}_{2} \mathrm{PO}_{4} / \mathrm{K}_{2} \mathrm{HPO}_{4}$ buffer $(\mathrm{pH} 7.4)$ containing $0.15 \mathrm{M} \mathrm{KCl}$. Homogenates were centrifuged at $500 \times \mathrm{g}$ for $15 \mathrm{~min}$ for removing nuclei and cell membranes. Next, centrifugation at $15000 \times \mathrm{g}$ for $30 \mathrm{~min}$ was performed to obtain mitochondria. Obtained supernatant was further centrifuged at 100 $000 \mathrm{xg}$ for $1 \mathrm{~h}$ for gaining microsomal pellet. The mitochondrial and microsomal pellets were diluted in $100 \mathrm{mM} \mathrm{KH}_{2} \mathrm{PO}_{4} / \mathrm{K}_{2} \mathrm{HPO}_{4}$ buffer $(\mathrm{pH} 7.4)$ containing $0.15 \mathrm{M} \mathrm{KCl}$ and $20 \%(\mathrm{w} / \mathrm{v})$ glycerol. Suspended mitochondrial fraction (volume ranging from 2 to $3 \mathrm{ml}$ ) containing $20-50 \mathrm{mg}$ of protein per $1 \mathrm{ml}$ was divided into $100 \mu \mathrm{l}$ subsamples. Similarly, microsomal fraction (volume ranging from 1 to $2 \mathrm{ml}$ ) containing approx. $20 \mathrm{mg}$ of protein per $1 \mathrm{ml}$ was divided into $100 \mu \mathrm{l}$ subsamples. The subsamples (containing at least $1 \mathrm{mg}$ of protein) were then frozen in $-80^{\circ} \mathrm{C}$ for further analyses. Protein content was determined after Lowry et al. (Lowry et al., 1951) with bovine serum albumin (BSA) as a standard. Temporal differences in AE were analysed in both tissue types based on microsomal isolates pooled from various individuals.

\subsubsection{Determination of aromatization in model species}

Aromatisation efficiency was determined in the mitochondrial and microsomal fractions of both, gill and gonadal tissues, by the tritiated water release method as described in Shimizu et al. (Shimizu et al., 1995) with some modifications. Both fractions (1 mg) were incubated in glass tubes in temperature gradient $4^{\circ} \mathrm{C}-23^{\circ} \mathrm{C}$ (tested temperatures were $4,5,6,7,8,9,10,11,18,23^{\circ} \mathrm{C}$ ) for $1 \mathrm{~h}$ in a final $1 \mathrm{~mL}$ volume in the presence of 100 $\mathrm{mM}$ Tris- $\mathrm{HCl}$ buffer of various pHs (pH 6.0, 6.6, 7.0, 7.6, 8.0, 8.6 and 9.0), $10 \mu \mathrm{M}[1 \beta-$ ${ }^{3} \mathrm{H}$ ]-androstenedione (with specific activity ranging from 150 to $200 \mathrm{DPM} / \mathrm{pmol}$ ) and 200 $\mu \mathrm{M}$ NADPH. First, temperature-based changes in AE were studied in order to select temperature window in which the process is most efficient. Next, the effect of $\mathrm{pH}$ on $\mathrm{AE}$ was analysed. In order to study similarity of an enzyme catalysing aromatization in bivalves to vertebrate aromatase, $1 \mathrm{mg}$ of microsomal fraction isolated from gonads characterized by high AE was incubated for 1 hour in the presence of letrozole, anastrozole and ketoconazole at concentrations of $0.1 \mathrm{mM}, 0.25 \mathrm{mM}, 0.5 \mathrm{mM}$ and 1 $\mathrm{mM}$. 
226 Next, organic metabolites and the excess of substrate were removed from the aqueous

227

228

229

230

231

232

233

234

235

236

237

238

239

240

241

242

243

244

245

246

247

248

249

250

251

252

253

254

255

256

257

258

259

260

261

262

263

phase by extraction with methylene chloride $(3 \mathrm{~mL})$. The samples were further centrifuged at $4000 \times \mathrm{g}$ for $15 \mathrm{~min}$. After centrifugation, $5 \%$ activated charcoal ( $2 \mathrm{~mL})$ was added to the aqueous phase, the solution was shaken for 2 min at room temperature and covered probes were left overnight. The next day, the solution was centrifuged at $4000 \times \mathrm{g}$ for $1 \mathrm{~h}$ and afterwards the collection of supernatant was performed. The supernatant was mixed with $4 \mathrm{~mL}$ of scintillation liquid and the solution was analysed using Beckman LS $6000 \mathrm{IC}$ counter. AE was assessed as tritium release to water from $1 \beta-{ }^{3} \mathrm{H}$ of androstenedione upon aromatization and was expressed as DMP (Disintegrations Per Minute) per hour per milligram protein and calculated as $\mathrm{pmol} / \mathrm{h} / \mathrm{mg}$ protein.

\subsection{Biosynthesis of estrogens - in vivo study}

15 blue mussels collected in spring 2018 were kept at $6^{\circ} \mathrm{C}$ and further individually transferred to glass beakers with aerated artificial seawater $(200 \mathrm{~mL})$ treated with 500 $\mu \mathrm{L}{ }^{13} \mathrm{C}_{3}$-labelled steroid mixture (4-Androstene-3,17-dione-2,3,4-13 $\mathrm{C}_{3}$ or Testosterone$2,3,4-{ }^{13} \mathrm{C}_{3}$ in acetonitrile) at the final concentration of $250 \mathrm{ng} / \mathrm{mL}$ and $1000 \mu \mathrm{L}$ of algae suspension. The control sample consisted of specimens transferred to glass beakers containing $200 \mathrm{~mL}$ of seawater, $500 \mu \mathrm{L}$ of acetonitrile and $1000 \mu \mathrm{L}$ of algae suspension. Next, beakers were placed in a water bath at a temperature of $6^{\circ} \mathrm{C}$ for two hours. After the two-hour incubation period the temperature was gradually increased to $8^{\circ} \mathrm{C}$ and the incubation continued for another 22 hours. After incubation, mussels were dissected, the whole soft tissue was frozen in liquid nitrogen and stored at $-80^{\circ} \mathrm{C}$. Subsequently, the soft tissue was prepared for solid phase extraction followed by analysis of steroids content using LC-MS/MS method. The above-described exposure to labelled androgens was repeated in identical conditions using 10 additional mussels on which, after soft tissue dissection, sexing was performed.

\subsubsection{Extraction procedure}

Sample extraction method was adopted from Vanhaecke et al. (Vanhaecke et al., 2011) and further modified as described below. Enzymatic digestion with subtilisin was used in order to support tissue homogenization via protein cleavage (Blasco, Van Poucke \& Van Peteghem, 2007). Frozen sample was transported into $20 \mathrm{~mL}$ glass flasks and thawed for $15 \mathrm{~min}$ in the presence of subtilisin enzyme $(0.4 \mathrm{mg} / 1 \mathrm{~g}$ tissue). Afterwards, samples were microwaved for $60 \mathrm{~s}$ at $100 \mathrm{~W}$, the content was transferred to $50 \mathrm{~mL}$ polypropylene tubes and homogenized using an Ultra-turrax instrument (Janke \& Kunkel, IKA-Labortechnik) for $1 \mathrm{~min}$. After adding $5 \mathrm{~mL}$ of methanol, samples were vortexed for $1 \mathrm{~min}$ and centrifuged $\left(5000 \times \mathrm{g}, 10 \mathrm{~min}, 4^{\circ} \mathrm{C}\right)$. Methanolic supernatant was collected and distilled water $(10 \mathrm{~mL})$ was added to the extract. The extract was concentrated on a Supel ${ }^{\mathrm{TM}}$-Select SPE HLB $(6 \mathrm{~mL}, 200 \mathrm{mg})$ column. The cartridge was

Peer) reviewing PDF | (2019:02:35004:1:1:NEW 26 Mar 2019) 
264

265

266

267

268

269

270

271

272

273

274

275

276

277

278

279

280

281

282

283

284

285

286

287

288

289

290

291

292

293

294

295

296

297

298

299

300

washed with water and hexane. The analytes were eluted with methanol. Upon evaporation under a stream of nitrogen, the dry residue of the eluate was dissolved in methanol/water mixture $(65: 35, \mathrm{v} / \mathrm{v})$.

\subsubsection{Steroids $-{ }^{13} \mathrm{C}_{3}$ identification - chromatographic and MS conditions}

Chromatographic separation was achieved using LC system coupled with MS (LCMS/MS-8050 Shimadzu, Japan). The mobile phase was composed of $0.1 \%$ formic acid in ultrapure water (phase A) and acetonitrile with addition of $0.1 \%$ formic acid (phase B). Analytes of interest were separated using a C-18 core-shell type column (Poroshell 120 EC-C18, Agilent Technologies, St. Clara, CA, USA) with dimensions $3.0 \times 100$ mm, 2.7 $\mu \mathrm{m}$ particle size with flow rate of $0.5 \mathrm{~mL} / \mathrm{min}$. To optimize the gradient elution phase $B$ was initially set at $31.1 \%$ level with successive increase to $55.1 \%$ during a 12 minute period. Next, the proportion of eluent B was increased to $100 \%$ during 0.9 min and then remained isocratic for a period of $3 \mathrm{~min}$. The autosampler' storage compartment was kept at $15^{\circ} \mathrm{C}$ to increase sample stability. The injected sample' volume was $1 \mu \mathrm{L}$. To minimize carry-over effect, the needle was flushed with methanol after injection. The total time of analysis was $16 \mathrm{~min}$. Next, the column rebalanced to the initial conditions. The injector needle was washed between injections with 50:50 acetonitrile-water and the needle seat back was flushed with acetonitrile-water mixture (50:50, v/v) at $35 \mu \mathrm{L} / \mathrm{s}$ for $2 \mathrm{~s}$ to evade contamination. LC-MS/MS was operated in the positive ion mode equipped with electrospray ionization source working with temperature-optimized conditions of the following components: interface: $300^{\circ} \mathrm{C}$, heater block: $200^{\circ} \mathrm{C}$, desolvation line (DL): $200^{\circ} \mathrm{C}$ and gas flows: drying gas $\left(\mathrm{N}_{2}\right): 10 \mathrm{~L} / \mathrm{min}$, nebulising gas $\left(\mathrm{N}_{2}\right)$ : $3 \mathrm{~L} / \mathrm{min}$ and heating gas (air): $10 \mathrm{~L} / \mathrm{min}$. Capillary voltage was maintained at $3 \mathrm{kV}$. Data were acquired in scheduled MRM mode using a detection window. The device was calibrated and tuned in agreement with procedures recommended by the manufacturer. Data acquisition and analysis of chromatograms were processed with LabSolution software (Shimadzu, Japan). The acquisition range in MS scanning mode was from 50 to $400 \mathrm{~m} / \mathrm{z}$ with a spectra rate of $1 \mathrm{~Hz}$. Each sample was analysed in triplicate. Details concerning $\mathrm{m} / \mathrm{z}$ values of precursor and product ions and exemplary chromatograms for all analysed steroids are presented in Table 1 and Fig. 1. LC-MS/MS method the LOQ was determined at $0.08 \mathrm{ng} / \mathrm{g}$ for $\mathrm{E} 1-{ }^{13} \mathrm{C}_{3}$ and $17 \beta \mathrm{E} 2-{ }^{13} \mathrm{C}_{3}, 0.06 \mathrm{ng} / \mathrm{g}$ for $\mathrm{A}-{ }^{13} \mathrm{C}_{3}$ and T${ }^{13} \mathrm{C}_{3}$

\subsection{Statistical analysis}

The statistical significance of differences between groups was verified with the nonparametric Kruskal-Wallis ANOVA test and the significance level was set at $p<0.05$. All statistical analyses were carried out in STATISTICA 13.0 software.

3. Results 
301

302

303

304

305

306

307

308

309

310

311

312

313

314

315

316

317

318

319

320

321

322

323

324

325

326

327

328

329

330

331

332

333

334

335

336

337

338

339

\subsection{The effect of temperature and $\mathrm{pH}$ on $\mathrm{AE}$}

Differences in aromatase efficiency were found when the process was analysed in various temperature conditions (Dataset S1). In the temperature range from $4^{\circ} \mathrm{C}$ to $5^{\circ} \mathrm{C}$ AE was low both in gills ( $10 \%$ of maximal activity recorded) and in gonads ( $5 \%$ of maximal activity) of the blue mussel. An increase of aromatase efficiency ( $\mathrm{pmol} / \mathrm{h} / \mathrm{mg}$ protein) was observed in temperatures above $5^{\circ} \mathrm{C}$. In the temperature range from $8^{\circ} \mathrm{C}$ to $9^{\circ} \mathrm{C} \mathrm{AE}$ was the highest with $41.66 \mathrm{pmol} / \mathrm{h} / \mathrm{mg}$ protein in the microsomal fraction of gills and $58.37 \mathrm{pmol} / \mathrm{h} / \mathrm{mg}$ protein in the microsomal fraction of gonads (Fig. $2 \mathrm{~A}$ ). Aromatization in temperatures above $8^{\circ} \mathrm{C}$ resulted in a lower substrate consumption and thus decreased production of tritiated water (lower efficiency). Room temperature $\left(23^{\circ} \mathrm{C}\right)$ resulted in negligible amounts of ${ }^{3} \mathrm{H}_{2} \mathrm{O}$ produced, i.e. $8 \%$ (gills) and $12 \%$ (gonads) of maximal $A E$ (Fig. 2A). Since the highest $A E$ occurred in $8-9^{\circ} \mathrm{C}$, pH related differences in $\mathrm{AE}$ were performed in controlled temperature conditions using gill and gonad subcellular fractions (Dataset S2). The process was stable in $\mathrm{pH}$ range from 7.6 to 9.0 for gills and showed similar levels of the $A E-41.83 \mathrm{pmol} / \mathrm{h} / \mathrm{mg}$ protein on average. Similarly, in microsomes from gonads aromatization level was stable and led to the production of about $51.89 \mathrm{pmol} / \mathrm{h} / \mathrm{mg}$ protein in the $\mathrm{pH}$ range from 7.0 to 8.6 (Fig. 2B). In $\mathrm{pH}$ levels from 6.0 to $7.0 \mathrm{AE}$ was lower than in the remaining pHs (Fig. 2B). No statistically significant differences in $\mathrm{AE}$ measured in $\mathrm{pH}$ levels from 7.6 to 9.0 were found, thus in further analyses physiological pH 7.6 was used. Each subsequent $A E$ measurements in the microsomes and mitochondria isolated from the bivalve tissues were conducted in optimal conditions, at $8^{\circ} \mathrm{C}$ and $\mathrm{pH}$ 7.6. AE was also checked in conditions such as the absence of NADPH and in denaturated microsomes. In both cases, the efficiency of AE decreased by min. $70 \%$ (Table S1).

\subsection{Seasonal changes in $A E$}

Statistically significant seasonal differences in AE were found (Fig. 3). The most efficient aromatization was recorded in mussels collected in spring in microsomal fraction originating from both analysed tissues; $31.75 \pm 7.51 \mathrm{pmol} / \mathrm{h} / \mathrm{mg}$ protein in gill and 39.34 $\pm 4.25 \mathrm{pmol} / \mathrm{h} / \mathrm{mg}$ protein in gonad. In mussels collected in summer and autumn seasons $A E$ decreased by $50 \%$ when compared to spring and equalled to $13.84 \pm 3.27$ $\mathrm{pmol} / \mathrm{h} / \mathrm{mg}$ protein in gills and $15.29 \pm 2.28 \mathrm{pmol} / \mathrm{h} / \mathrm{mg}$ protein in gonads. The lowest AE equaled to $3.17 \pm 1.22 \mathrm{pmol} / \mathrm{h} / \mathrm{mg}$ protein in gills and $1.84 \pm 1.02 \mathrm{pmol} / \mathrm{h} / \mathrm{mg}$ protein in gonads and was measured in winter season (Fig. 3, Dataset S3). No statistically significant changes in $A E$ between analysed tissues in each season were found except for winter, where $A E$, despite being at the lowest level, was twice as high in gills as in gonads. However, a trend towards more efficient aromatization in blue mussels gonads compared to gills can be seen in all seasons but winter.

3.3. Sex-related differences in AE in mitochondrial and microsomal fractions from gills and gonads 
340 Sex- and fraction-related differences in AE were also confirmed. In females, AE was 341 higher in the mitochondrial fraction compared to the microsomal fraction isolated from 342 both tissues. Activity of an aromatase-like enzyme complex catalysing aromatization in

343 gills was $33.73 \pm 6.59 \mathrm{pmol} / \mathrm{h} / \mathrm{mg}$ of protein in microsomes and $43.12 \pm 2.70 \mathrm{pmol} / \mathrm{h} / \mathrm{mg}$ 344 of protein in the mitochondrial fraction. In gonadal tissue, its activity equalled to $44.78 \pm$ $1.90 \mathrm{pmol} / \mathrm{h} / \mathrm{mg}$ of protein in microsomes, while in the mitochondria 1.6-fold higher activity was measured $(73.94 \pm 2.41 \mathrm{pmol} / \mathrm{h} / \mathrm{mg}$ protein). Similarly, in males a higher AE in the mitochondrial fraction compared to the microsomal one was found. In gills, aromatization occurring at $29.77 \pm 8.41 \mathrm{pmol} / \mathrm{h} / \mathrm{mg}$ of protein was confirmed in microsomes, and at $62.97 \pm 6.56 \mathrm{pmol} / \mathrm{h} / \mathrm{mg}$ of protein in the mitochondria. In gonads, higher $A E$ was found in the mitochondrial fraction $(56.71 \pm 1.85 \mathrm{pmol} / \mathrm{h} / \mathrm{mg}$ protein) compared to the microsomes (33.91 $\pm 6.60 \mathrm{pmol} / \mathrm{h} / \mathrm{mg}$ protein). In females, statistically significant differences in $A E$ between tissues were found. In microsomal fraction of gonads $A E$ was $30 \%$ higher than in the same fraction isolated from gills. Similarly, in mitochondrial fraction isolated from gonads $A E$ was 1.7 times higher than in mitochondrial fractions from gills. In males, no statistically significant differences in $\mathrm{AE}$ measured in both tissues were found in microsomal fraction. However, AE was higher in gill mitochondria than in gonadal mitochondria $(p<0.05)$. Sex-related differences in AE included 1.3 times higher $A E$ in female gonads when compared to male gonads (both fractions) and 1.5 times higher aromatization in mitochondrial fraction isolated from male gills when compared to female gills (Fig. 4, Dataset S4).

\subsection{The effect of inhibitors on $A E$ in gonads of $M$. trossulus}

The effect of inhibitors on $A E$ is presented in Dataset S5 (raw data). In the presence of $1 \mathrm{mM}$ letrozole $100 \%$ increase in $A E$ in subcellular fraction of gonads was found even in the highest concentration of the inhibitor $(81.57 \pm 3.62 \mathrm{pmol} / \mathrm{h} / \mathrm{mg}$ of protein). Also in the presence of $0.5 \mathrm{mM}$ anastrozole there was an evident and significant increase in $\mathrm{AE}$ (almost $40 \%, 66.43 \pm 1.83 \mathrm{pmol} / \mathrm{h} / \mathrm{mg}$ of protein) when compared to the control $(p<0.05)$. The inhibiting effect of anastrozole was only observed at the concentration of $1 \mathrm{mM}$, resulting in inhibition of aromatization by $50 \%(21.11 \pm 0.62 \mathrm{pmol} / \mathrm{h} / \mathrm{mg}$ of protein) when compared to the control (Fig. 5). Inhibitory effect of ketoconazole was confirmed in all tested concentrations. Inhibition was linear and the efficiency of the process gradually decreased along used concentration gradient (Fig.5).

\subsection{Estrogens synthesis in vivo and identification of other steroids via mass spectrometry}

In $90 \%$ of individuals (18 out of 20 ) both androgens $-{ }^{13} \mathrm{C}_{3}$ and estrogens $-{ }^{13} \mathrm{C}_{3}$ were identified. In bivalves exposed to Testosterone-2,3,4- ${ }^{13} \mathrm{C}_{3}\left(\mathrm{~T}-{ }^{13} \mathrm{C}_{3}\right)$ both $\mathrm{T}-{ }^{13} \mathrm{C}_{3}$ and $4-$ Androstene-3,17-dione-2,3,4- ${ }^{13} \mathrm{C}_{3}\left(\mathrm{~A}-{ }^{13} \mathrm{C}_{3}\right)$ were identified but at different concentrations. High concentration of $\mathrm{T}^{-13} \mathrm{C}_{3}(8.48 \pm 3.29 \mathrm{ng} / \mathrm{g}$ wet weight) and eight 
380

times lower concentrations of 4-Androstene-3,17-dione-2,3,4-13 $\mathrm{C}_{3}(0.96 \pm 0.30 \mathrm{ng} / \mathrm{g} \mathrm{w}$. w.) were detected (Fig. 6, Tab. S2). Similarly, an exposure to $A-{ }^{13} C_{3}$ resulted in detection of both, $T-{ }^{13} C_{3}$ and $A-{ }^{13} C_{3}$ in analysed tissues. In mussels exposed to $T-{ }^{13} C_{3}$ the presence of $17 \beta$-estradiol-2,3,4- ${ }^{13} \mathrm{C}_{3}(0.97 \pm 0.44 \mathrm{ng} / \mathrm{g} \mathrm{w}$. w. $)$ was confirmed, whereas in those exposed to $A-{ }^{13} C_{3}$, Estrone-2,3,4- ${ }^{13} C_{3}(2.75 \pm 1.72 \mathrm{ng} / \mathrm{g} \mathrm{w}$. w.) was found (Fig. 6, Tab. S2). The analysis of remaining labelled steroids revealed mutual and reversible conversion of androgens with $A-{ }^{13} C_{3}$ transformed into $T-{ }^{13} C_{3}$. Similarly, reversible transformation of estrogens was observed with $E 1-{ }^{13} C_{3}$ converted to $17 \beta E 2-$ ${ }^{13} \mathrm{C}_{3}$. No sex-related difference in the steroid uptake or synthesis was found (Tab. S2 A, B).

\section{Discussion}

In marine invertebrates, activities of selected steroidogenic enzymes (3ß-hydroxysteroid dehydrogenase, 17a-hydroxylase, aromatase and aromatase-like enzyme) measured in microsomal fraction from various tissues were detected at very low levels, or not detected at all. For example, in coral Pocillopora damicornis aromatase-like activity was determined by measuring the conversion of testosterone to $17 \beta$-estradiol using ELISA test and the resulting activity was calculated as 10-1000 fg E2/min/mg protein (Rougée, Richmond \& Collier, 2015). In sea urchin Paracentrotus lividus P450-aromatase activity measured using an isotopic method equalled to $0.3-0.8 \mathrm{pmol} / \mathrm{h} / \mathrm{mg}$ protein (Barbaglio et al., 2007). In Lavado et al. (Lavado, Janer \& Porte, 2006), an isotopic method with $1 \beta-{ }^{3} \mathrm{H}$ androstenedione as a substrate for detection of aromatase activity in microsomal fraction from gonads and digestive gland of $M$. edulis was applied. At the time of measurement, a possibility of unspecific cross-reactivity was not taken into consideration, hence the authors presented their results as a measurement of steroidogenic P-450-aromatase activity. In spite of methodological similarities, described in Lavado et al. (Lavado, Janer \& Porte, 2006) enzymatic activities were much lower than presented in our work and ranged from 0.3 to $3.0 \mathrm{pmol} / \mathrm{h} / \mathrm{mg}$ protein depending on type of tissue and exposure type. The referred measurement of aromatase activity was performed under laboratory controlled conditions at $25^{\circ} \mathrm{C}$. Since comparable low activities were obtained in our study in similar temperature regime, we believe that the main reason behind differences in aromatization rate obtained in our and in Lavado et al. (Lavado, Janer \& Porte, 2006) is temperature in which the actual measurement was performed. After analysing $A E$ in various temperature regimes in in vitro and seasonally, it became clear that aromatization in bivalves is a temperaturedependent process and temperature is a strong limiting factor for it to occur efficiently. That is especially important when taking into account mussels inhabiting colder temperate areas such as the Baltic Sea. It has to be, however, noted, that bivalves from warmer areas may have different temperature optimum for aromatization to be efficient than those inhabiting colder regions. 
420 In Mytilus edulis complex inhabiting temperate and polar waters also gametogenesis

421

422

423

424

425

426

427

428

429

430

431

432

433

434

435

436

437

438

439

440

441

442

443

444

445

446

447

448

449

450

451

452

453

454

455

456

457

458

459 belongs to temperature-related processes which is initiated in late winter and proceeds until early summer when spawning takes place. In the Baltic Sea, water usually reaches temperatures of $8-9^{\circ} \mathrm{C}$ in spring, thus allowing for various metabolic processes including androgen aromatization to start. During that time the need for estrogens may also increase. In our previous studies performed on blue mussels collected from the Gulf of Gdańsk (Poland), the lowest steroids content was recorded in winter when water temperature is the lowest. In spring, an increase in the amount of estrogen was identified with the highest estrogens concentration found in mussels collected during summer season (Smolarz et al., 2018). The estrogen' content in tissues decreased in autumn together with a temperature decrease. The highest level of estrogen in mussel tissues found in summer is most likely related not to an increased efficiency of steroidogenesis, but rather to efficient uptake of steroids from the ambient environment as it was already proved by various studies including our own (Schwarz et al., 2017a,b, 2018; Smolarz et al., 2018). Active steroidogenesis occurs only in spring when the level of sex steroids in the ambient environment is low. That may also be related to the fact that the administration of hormones from the outside simply inhibits their synthesis, a phenomenon well-known from research on vertebrates. Optimization (consideration of temperature) of the isotopic method designed for quantification of aromatization allowed for obtaining aromatisation rate in studied blue mussels at levels similar to those available for higher organisms (Emoto \& Baird, 1988). Interestingly, a strong dependency of aromatization efficiency (due to changes in aromatase activity) on temperature, like the one observed in our study, has already been described in various species displaying temperature-dependent sex determination such as reptiles, including crocodilians, turtles and lizards (Crews et al., 1994). In these species aromatase activity remains universally low with steroidogenesis often beginning very early. Indeed, at the beginning of the thermosensitive period an increase in aromatase activity appears and is temperature-specific with the temperature window depending on species. In marine and freshwater turtles rising temperatures cause an exponential increase of aromatase activity, whereas in lower temperatures aromatase activity remains low. Distinct levels of aromatase activity drive the differentiation of indifferent gonads into sex-specific reproductive apparatus, that, once established, becomes no longer affected by temperature changes (Manolakou, Lavranos \& Angelopoulou, 2006). Recent studies also highlight a possibility of epigenetic regulation of the sex determination in reptiles mediated by cold-inducible RNA binding protein (Cirpb) (Georges \& Holleley, 2018). The presence of aromatase (or aromatase-like enzyme) in bivalves has not been confirmed so far either on a protein or on a genetic levels but verification of its (or a similar gene catalysing aromatization in this group of organisms) localization could result in the discovery of mechanisms behind sex determination similar as those in reptiles. According to Castro and others (Castro, Santos \& Reis-Henriques, 2005), the 
460 probability of aromatase gene ortholog being present in Mollusca genome is quite high

461

462

463

464

465

466

467

468

469

470

471

472

473

474

475

476

477

478

479

480

481

482

483

484

485

486

487

488

489

490

491

492

493

494

495

496

497

498

499 as the presence of a MHC-paralog gene similar to vertebrates was recently confirmed. The recently published study by Thitiphuree, Nagasawa \& Osada (2019) suggests that aromatisation, if occurring in bivalves, is not based on vertebrates type aromatase, but on other enzyme from cytochrome P450 family.

Since the production of tritiated water may be related to the presence of aromatase as well as to another enzyme belonging to the cytochrome P450 family, we decided to use known vertebrate aromatase inhibitors (letrozole, anastrozole and ketoconazole) in order to confirm that aromatisation in bivalves is catalused by aromatase in the model species. Letrozole affects aromatase in a variety of tissues including human placenta $\left(\mathrm{IC}_{50}-11 \mathrm{nM}\right)$ and rat ovarian microsomes $\left(\mathrm{IC}_{50}-7 \mathrm{nM}\right)$, hamster ovarian cells $\left(\mathrm{IC}_{50}-20\right.$ $\mathrm{nM})$, human breast ( $\left.\mathrm{IC}_{50} 0.14-0.8 \mathrm{nM}\right)$ or JEG-3 human choriocarcinoma cells $\left(\mathrm{IC}_{50} 0.07\right.$ $-0.45 \mathrm{nM}$ ) (Haynes et al., 2003). It binds to the iron in heme moiety of CYP-450, whereas the cyanobenzyl moiety partially mimics the steroid backbone of the enzyme's natural substrate androstenedione (Bhatnagar, 2007). In non-cellular systems, letrozole is 2-5 times more potent than anastrozole. Anastrozole hinders human aromatase by $50 \%$ at a concentration of $0.043 \mathrm{pg} / \mathrm{ml}(15 \mathrm{nM})$ (Hortobagyi \& Buzdar, 1998). In our study, both letrozole and anastrozole proved to be characterized by low or non-existing inhibitory affinity to the enzyme catalyzing aromatization in bivalves. Atypical mechanism of action of letrozole was also found since the drug not only did not inhibit the reaction, but stimulated aromatization process in tested bivalves. Similarly to letrozole, the lower doses of anastrozole used in our study induced the aromatization rate in mussels, but higher concentration of anastrozole indeed inhibited the process by over $50 \%$. Ketoconazole $(\mathrm{KZ})$ is characterized by direct in vitro inhibition of the human ovarian enzymes $3 \beta$-hydroxysteroid dehydrogenase and 17-hydroxylase activity. These two enzymes are proven to be essential for the formation of C-19 steroids: androstenedione and testosterone (DiMattina et al., 1988). Furthermore, KZ has been shown to inhibit cholesterol side chain cleavage enzyme in both the adrenal and testis. Santen et al. (Santen et al., 1983) concluded that ketoconazole inhibits several other cytochrome P-450-dependent steroid hydroxylases. In vitro studies (Loose et al., 1983; Nagai et al., 1986) provided evidence that ketoconazole inhibits hydroxylation of deoxycorticosterone and renal 24-hydroxylase suggesting that $K Z$ indeed belongs to nonspecific inhibitors of many cytochrome P-450 enzymes. KZ is also widely used as antifungal drug exerting its antifungal effect by inhibition of ergosterol biosynthesis and it appears to be a potent inhibitor of triglycerides and phospholipids synthesis in fungi (Van Tyle, 1984). In our study, only ketoconazole application brought expected results as it successfully inhibited tritiated water production in mussel gonads in all tested concentrations. Summarizing, selected specific (low spectrum) inhibitors of mammalian aromatase were not effective as inhibitors (letrozole) or only effective when applied in high concentrations (anastrozole), suggesting that the structure of the protein catalyzing 
500 aromatization in mussels differs from the one known as mammalian aromatase. Only $501 \mathrm{KZ}$ inhibitory potency was confirmed, but since the pharmaceutical is characterized by a 502 high-spectrum of action it is possible that it can also inhibit aromatase-like protein 503 belonging to the CYP 450 family that happens to catalyse aromatization in mussels. 504 Hence, we believe that the presence of non-specific cross-reactivity with aromatization 505 catalyzed not by aromatase typical for vertebrates but by an enzyme similar in function 506 but different in structure (belonging to CYT P450 family) is occurring in molluscs. The 507 results of recently published molecular identification of steroidogenesis-related genes in 508 scallops suggest that the occurrence of vertebrate type aromatase in bivalves is unlikely 509 (Thitiphuree, Nagasawa \& Osada, 2019), what is also supported by the results of our study. However, aromatisation (conversion of androgens to estrogens) may still take 512 ("aromatase-like" as suggested by us) or a protein coded by CYP 3 gene (as suggested 513 by Thitiphuree et al., 2019). Thus, more research has to be done in order to identify and 514 describe the protein catalysing aromatisation.

515 Our results also indicate that in mitochondrial fraction aromatization process appeared 516 to be more efficient than in microsomal fraction. Mitochondrial fraction is protein-rich 517 and contains enzymes more efficiently hydroxylating labelled substrate than those found 518 in the microsomal fraction (Felty \& Roy, 2005). In vertebrates, steroid synthesis starts 519 from synthesis of pregnenolone from cholesterole, and the reaction is operated by mitochondrial complex of cholesterol desmolase (protein type group CYT P450 CYP11A) (Milczarek et al., 2008; Miller, 2011; Ramalho-Santos \& Amaral, 2013). Synthesized pregnenolone is further relocated to endoplasmic reticulum, where the synthesis of progesterone takes place. Progesterone, depending on the tissue it originates from, then becomes the precursor of various steroid hormones. Based on the final stage of estrogen synthesis, in vertebrates aromatase is active mainly in the microsomal fraction (Carreau et al., 2003), but can also be found in the mitochondria of human placenta (Smith et al., 1999; Manolakou, Lavranos \& Angelopoulou, 2006). Our results suggest that aromatase-like enzyme catalyzing aromatisation in bivalves is characterized by similar to vertebrate' aromatase mechanism of action and is in affinity with both the mitochondrial and microsomal fractions regardless the tissue studied. Our results also highlight that efficiency of aromatisation in female mussels is relatively high in mitochondrial fraction isolated from the gonadal tissue. Latest studies report that bivalves from genus Mytilidae are able to uptake large amounts of progesterone (Schwarz et al., 2018), testosterone (Schwarz et al., 2017b) and 17ß-estradiol (Schwarz et al., 2017a) from the ambient environment. This high steroids uptake potential was also confirmed in our study with $A-{ }^{13} C_{3}$ and $T-{ }^{13} C_{3}$ detected in mussel tissues after exposure to labelled substrate. Those androgens were further metabolized to estrogens: estrone-2,3,4- ${ }^{13} \mathrm{C}_{3}\left(\mathrm{E} 1-{ }^{13} \mathrm{C}_{3}\right)$ and $17 \beta$-estradiol-2,3,4- 
539

540

541

542

543

544

545

546

547

548

549

550

551

552

553

554

555

556

557

558

559

560

561

562

563

564

565

566

567

568

569

570

571

572

573

574

575

576

577

578

${ }^{13} \mathrm{C}_{3}$. According to our knowledge, this is the first comprehensive study fully documenting the occurrence of aromatization process taking place in bivalve tissues. In our previous studies (Hallmann et al., 2016; Smolarz et al., 2018) testosterone level in M. trossulus ranged from 3 to $14 \mathrm{ng} / \mathrm{g}$ of wet weight, depending on the season and tissue type. These values correspond well with the levels of $T-{ }^{13} \mathrm{C}_{3}$ intercepted by mussels in the in vivo experiment. The amount of naturally occurring estrone ranged from 0.5 to $3.5 \mathrm{ng} / \mathrm{g}$ w.w., and also corresponded with $\mathrm{E}^{1-13} \mathrm{C}_{3}$ concentration in the mussel tissues. The level of natural $17 \beta$-estradiol oscillated between 1 and $9 \mathrm{ng} / \mathrm{g}$ w.w., but the level of synthesized $17 \beta E 2-{ }^{13} C_{3}$ was much lower, near $1 \mathrm{ng}$ per gram of wet tissue. At the same time no sex-related differences in remaining androgens- ${ }^{13} \mathrm{C}_{3}$ and synthesized estrogens- ${ }^{13} \mathrm{C}_{3}$ were found. As described above, incubation of blue mussels with $T-{ }^{13} C_{3}$ or $A-{ }_{13} C^{3}$ resulted in the formation of $T-{ }^{13} C_{3}, A-{ }^{13} C_{3}, E 1-{ }^{13} C_{3}$ and $17 \beta E 2-$ ${ }^{13} \mathrm{C}_{3}$. Such interconversion of steroids is possible when $17 \beta$-hydroxysteroid dehydrogenase (17ßHSD) is present in mussel tissues and active in the presence of both, androgen and estrogen substrates. In mollusc, 17ßHSD catalysed conversion of the estrone to $17 \beta E 2$ and the enzymatic pathways is already described (Baker, 2001; Scott, 2012). In the performed exposure experiment, a substrate-specific preference was observed since the uptake of $T$ was three times higher than $A$. The two hormones can therefore be used as substrates in aromatization and estrogen synthesis. Higher affinity for testosteron observed in blue mussels can possibly be related to the usage of $T$ in a synthesis of $17 \beta$-estradiol while androstenedione can be used in estrone (E1) synthesis, the latter occurring in lower concentration in bivalve tissues than E1 (Smolarz et al., 2018). In females, estrogens seem to be important in reproduction and immune response regulation (Stefano et al., 2003; Ketata et al., 2008; Cubero-Leon et al., 2010). In male mussels, the role of estrogens may be similar to their role in vertebrates, where E2 initiates testicular maturation and spermatogenesis advancing the gamete' development (Carreau et al., 2003).

We have proven that bivalves do have a veritable factory necessary for estrogen production and thus are able to synthesise estrogens, something that has evaded other researchers over the past 70 years. Our results also indicate that bivalves have a great potential of uptaking steroids from the ambient environment in high doses, but only a small part of them will be aromatised. Taking into account mussels ability to concentrate the steroids from ambient environment and their high clearance rate (estimated at $40 \mathrm{ml}$ per hour per animal for T (Schwarz et al. 2017b)), all added androgens could have been absorbed and subsequently modified by the mussels. Hence, obtained in experimental conditions conversion rate of androgens to estrogens can be regarded as low, thus esterification of remaining sex steroids is highly expected. Various authors reported bioaccumulation of $17 \beta$-estradiol in the form of fatty acid esters in bivalve tissues (Puinean \& Rotchell, 2006, Peck et al., 2007; Scott, 2018). Moreover, in Schwarz et al. (2017b), apart from esters binding $T$, dihydrotestosterone, $5 \alpha$-androstan- $3 \beta, 17 \beta$-diol 
579

580

581

582

583

584

585

586

587

588

589

590

591

592

593

594

595

596

597

598

599

600

601

602

603

604

605

606

607

608

609

610

611

612

613

614

615

616

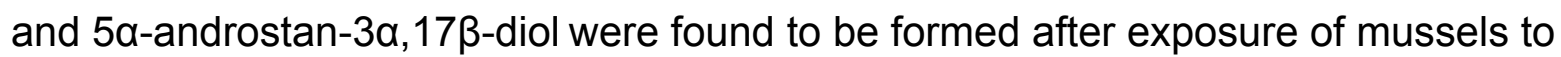
similar doses of labelled $\mathrm{T}$. The failure in detection of estrogen production by Schwarz et al. (2017b) can thus be related to the fact that, apart from temperature and season, labelled estrogens peaks (low-yield fraction) could have been missed due to the presence of mentioned above high-yield androgen metabolites possibly reducing chromatogram' readability.

In bivalves estrogens bind to specific receptors but molecular pathway of steroids in general is not yet fully recognized. The presence of estrogen receptor (ER) and estrogen response element (ERE) was indeed confirmed in the genome of the Sydney rock oyster Saccostrea glomerata (Tran et al., 2016) whereas in the Pacific oyster $C$. gigas cgER estrogen receptor was found to be homologous in nearly $90 \%$ with the human ERa and ERß located in the nuclei of follicle cells (Matsumoto et al., 2007). In M. edulis not only the presence of ER2 receptor homologous with human ER $\beta$ was reported, but also its activation by estrogens in the early stage of gametogenesis was confirmed (Ciocan et al., 2010). The occurrence of different class of nuclear receptors able to bind steroids in mollusks has also been suggested after Di Cosmo et al. (Di Cosmo, 1998; Di Cosmo et al., 2002) proved that the binding proteins for progesterone and $17 \beta$-estradiol in $O$. vulgaris have the ability to bind to DNA. Binding of vertebrate type estradiol-17ß to invertebrate estrogen receptors is, however, a low affinity process (Thornton, Need \& Crews, (2003). Hence, without genomic description of the binding proteins for steroids (Thornton, Need \& Crews, 2003; Bertrand et al., 2004; Bridgham et al., 2014) it is not possible to confirm whether estrogens are successfully binding to them and therefore give a biological response in mollusks (Björnström \& Sjöberg, 2005; Keay, Bridgham \& Thornton, 2006; Bannister et al., 2013; Schwarz et al., 2017a). In vertebrates, estrogens may also react in a non-genomic way by attaching to a receptor located on the cellular membrane. The non-genomic effect of estrogens may affect the signaling pathways of MAPK kinases, tyrosine and lipid kinases (Simoncini \& Genazzani, 2003; Björnström \& Sjöberg, 2005) and this interaction could be similar in bivalve mollusks. In our study, more efficient aromatization of estrogens in mitochondria than in microsomes isolated from bivalves was found. Vertebrate models proved that estrogens easily penetrate the mitochondria through diffusion and endocytosis and regulate the transcription of the mitochondrial genome in ERE sites (Felty \& Roy, 2005). In bivalve models ERE regions have not been found so far. However, in DUI species such as $M$. trossulus, estrogens can be involved in the regulation of sex determination linked to mtDNA inheritance pattern associated with sex-ratio bias (Zouros et al., 1994). This may explain estrogens synthesis during gonadal maturation and higher aromatization efficiency in spring.

Conclusions 
617 In our study, aromatisation of androgens by mitochondria and microsomes isolated from

618 gills and gonads of $M$. trossulus with temperature strongly influencing the efficiency of 619 the process was detected. High uptake of Testosterone-2,3,4- ${ }^{13} \mathrm{C}_{3}$ and 4-Androstene3,17-dione-2,3,4- ${ }^{13} \mathrm{C}_{3}$ and their conversion to $17 \beta$-estradiol-2,3,4- ${ }^{13} \mathrm{C}_{3}$ and Estrone$2,3,4-{ }^{13} \mathrm{C}_{3}$ was also identified. Thus, steroids in bivalves can be of endogenic and exogenic origin with estrogen' biosynthesis taking place only in the narrow temperature window (Spring) in mussels inhabiting colder temperate area. The vertebrate aromatase inhibitors such as letrozole and anastrozole had an unusual effect on mussels' AE; with the process being more rapid after their usage. Only highest dose of anastrozole and ketoconazole inhibited the aromatization process suggesting that the aromatase-like enzymatic complex belongs to large CYT450 family. This, and the fact that aromatisation was more efficient in mitochondrial and microsomal fractions mean that the aromatase-like enzymatic complex involved in aromatisation in bivalves is characterised by a different structure than vertebrates aromatase.

Baker ME. 2001. Evolution of 17ß-hydroxysteroid dehydrogenases and their role in androgen, estrogen and retinoid action. Molecular and Cellular Endocrinology DOI: 10.1016/S0303-7207(00)00414-7.

Bannister R, Beresford N, Granger DW, Pounds NA, Rand-Weaver M, White R, Jobling S, Routledge EJ. 2013. No substantial changes in estrogen receptor and estrogenrelated receptor orthologue gene transcription in Marisa cornuarietis exposed to estrogenic chemicals. Aquatic Toxicology 140-141:19-26 DOI: 10.1016/j.aquatox.2013.05.002.

Barbaglio A, Sugni M, Di Benedetto C, Bonasoro F, Schnell S, Lavado R, Porte C, Candia Carnevali DM. 2007. Gametogenesis correlated with steroid levels during the gonadal cycle of the sea urchin Paracentrotus lividus (Echinodermata: Echinoidea). Comparative Biochemistry and Physiology Part A: Molecular \& Integrative Physiology 147:466-474 DOI: 10.1016/j.cbpa.2007.01.682.

Bertrand S, Brunet FG, Escriva H, Parmentier G, Laudet V, Robinson-Rechavi M. 2004. Evolutionary genomics of nuclear receptors: from twenty-five ancestral genes to derived endocrine systems. Molecular Biology and Evolution 21:1923-1937 DOI: 10.1093/molbev/msh200.

Bhatnagar AS. 2007. The discovery and mechanism of action of letrozole. Breast Cancer Research and Treatment 105:7-17 DOI: 10.1007/s10549-007-9696-3.

Björnström L, Sjöberg M. 2005. Mechanisms of estrogen receptor signaling: convergence of genomic and nongenomic actions on target genes. Molecular Endocrinology 19:833-842 DOI: 10.1210/me.2004-0486. 
655

656

657

658

659

660

661

662

663

664

665

666

667

668

669

670

671

672

673

674

675

676

677

678

679

680

681

682

683

684

685

686

687

688

689

690

691

692

693
Blasco C, Van Poucke C, Van Peteghem C. 2007. Analysis of meat samples for anabolic steroids residues by liquid chromatography/tandem mass spectrometry. Journal of Chromatography A 1154:230-239 DOI: 10.1016/j.chroma.2007.03.090.

Bridgham JT, Keay J, Ortlund EA, Thornton JW. 2014. Vestigialization of an allosteric switch: genetic and structural mechanisms for the evolution of constitutive activity in a steroid hormone receptor. PLoS Genetics 10:e1004058. DOI: 10.1371/journal.pgen.1004058.

Callard G V, Tarrant AM, Novillo A, Yacci P, Ciaccia L, Vajda S, Chuang G-Y, Kozakov D, Greytak SR, Sawyer S, Hoover C, Cotter KA. 2011. Evolutionary origins of the estrogen signaling system: insights from amphioxus. The Journal of steroid biochemistry and molecular biology 127:176-88 DOI: 10.1016/j.jsbmb.2011.03.022.

Carreau S, Lambard S, Delalande C, Denis-Galeraud I, Bilinska B, Bourguiba S. 2003. Aromatase expression and role of estrogens in male gonad: a review. Reproductive biology and endocrinology: RB\&E 1:35.

Castro LFC, Santos MM, Reis-Henriques MA. 2005. The genomic environment around the aromatase gene: evolutionary insights. BMC evolutionary biology 5:43 DOI: 10.1186/1471-2148-5-43.

Ciocan CM, Cubero-Leon E, Puinean AM, Hill EM, Minier C, Osada M, Fenlon K, Rotchell JM. 2010. Effects of estrogen exposure in mussels, Mytilus edulis, at different stages of gametogenesis. Environmental Pollution 158:2977-2984 DOI: 10.1016/j.envpol.2010.05.025.

Di Cosmo A, Paolucci M, Di Cristo C, Botte , Ciarcia G. 1998. Progesterone receptor in the reproductie system of the female of Octopus vulgaris: characterization and immunolocalization. Molecular Reproduction and Development 50:451-460 DOI:10.1002/(SICI)1098-2795(199808)50:4<451:AID-MRD9>3.0.CO;2-H

Di Cosmo A, Di Cristo C, Paolucci M. 2002. A Estradiol-17 $\beta$ receptor in the reproductive system of the female of Octopus vulgaris: Characterization and immunolocalization. Molecular Reproduction and Development. DOI: 10.1002/mrd.10014.

Crews D, Bergeron JM, Bull JJ, Flores D, Tousignant A, Skipper JK, Wibbels T. 1994. Temperature-dependent sex determination in reptiles: Proximate mechanisms, ultimate outcomes, and practical applications. Developmental Genetics. DOI: 10.1002/dvg.1020150310.

Cubero-Leon E, Ciocan CM, Hill EM, Osada M, Kishida M, Itoh N, Kondo R, Minier C, Rotchell JM. 2010. Estrogens disrupt serotonin receptor and cyclooxygenase mRNA expression in the gonads of mussels (Mytilus edulis). Aquatic Toxicology 98:178-187 DOI: 10.1016/j.aquatox.2010.02.007.

Le Curieux-Belfond O, Moslemi S, Mathieu M, Séralini GE. 2001. Androgen metabolism in oyster Crassostrea gigas: evidence for 17beta-HSD activities and characterization of an aromatase-like activity inhibited by pharmacological

Peer] reviewing PDF | (2019:02:35004:1:1:NEW 26 Mar 2019) 
694

695

696

697

698

699

700

701

702

703

704

705

706

707

708

709

710

711

712

713

714

715

716

717

718

719

720

721

722

723

724

725

726

727

728

729

730

compounds and a marine pollutant. The Journal of steroid biochemistry and molecular biology 78:359-66

DiMattina M, Maronian N, Ashby H, Loriaux DL, Albertson BD. 1988. Ketoconazole inhibits multiple steroidogenic enzymes involved in androgen biosynthesis in the human ovary. Fertility and sterility 49:62-65

Emoto N, Baird A. 1988. The effect of tumor necrosis factor/cachectin on folliclestimulating hormone-induced aromatase activity in cultured rat granulosa cells. Biochemical and Biophysical Research Communications. DOI: 10.1016/S0006291X(88)81165-3.

Felty Q, Roy D. 2005. Estrogen, mitochondria, and growth of cancer and non-cancer cells. Journal of Carcinogenesis 4:1. DOI: 10.1186/1477-3163-4-1.

Finkelstein M, Neiman G, Mizrahi Y. 1985. Human placenta mitochondrial aromatasefact or artifact. Steroids 45:277-87

Foidart A, Silverin B, Baillien M, Harada N, Balthazart J. 1998. Neuroanatomical distribution and variations across the reproductive cycle of aromatase activity and aromatase-immunoreactive cells in the pied flycatcher (Ficedula hypoleuca). Hormones and behavior 33:180-96. DOI: 10.1006/hbeh.1998.1448.

Georges A, Holleley CE. 2018. How does temperature determine sex? Science 360:601-602 DOI: 10.1126/science.aat5993.

Hall PF. 1985. Cytochrome P-450: physiology of steroidogenesis. Annals of the New York Academy of Sciences 458:203-15

Hallmann A, Smolarz K, Konieczna L, Zabrzańska S, Belka M, Bączek T. 2016. LC-MS measurment of free steroids in mussels (Mytilus trossulus) from the southern Baltic Sea. Journal of pharmaceutical and biomedical analysis 117:311-15 DOI: 10.1016/j.jpba.2015.09.013.

Haynes BP, Dowsett M, Miller WR, Dixon JM, Bhatnagar AS. 2003. The pharmacology of letrozole. Journal of Steroid Biochemistry and Molecular Biology. DOI: 10.1016/S0960-0760(03)00384-4.

Hortobagyi GN, Buzdar AU. 1998. Anastrozole (Arimidex), a new aromatase inhibitor for advanced breast cancer: mechanism of action and role in management. Cancer investigation 16:385-390

Janer G, Sternberg RM, Leblanc GA, Porte C. 2005. Testosterone conjugating activities in invertebrates: Are they targets for endocrine disruptors? Aquatic Toxicology. DOI: 10.1016/j.aquatox.2004.11.024.

Lavado R, Janer G, Porte C. 2006. Steroid levels and steroid metabolism in the Mussel Mytilus edulis: The modulating effect of dispersed crude oil and alkylphenols. Aquatic Toxicology 78:S65-S72 DOI: 10.1016/j.aquatox.2006.02.018. 
731

732

733

734

735

736

737

738

739

740

741

742

743

744

745

746

747

748

749

750

751

752

753

754

755

756

757

758

759

760

761

762

763

764

765

766

767

768

Jianbin ZKCN. 2013. Sex steroid levels and expression patterns of estrogen receptor gene in the oyster Crassostrea angulata during reproductive cycle. Aquaculture. DOI:10.1016/j.aquaculture.2012.11.023

Kautsky N. 1982. Growth and size structure in a baltic Mytilus edulis population. Marine Biology. DOI: 10.1007/BF00397599.

Kautsky N, Evans S. 1987. Role of biodeposition by Mytilus edulis in the circulation of matter and nutrients in a Baltic coastal ecosystem Nils. Marine Ecology Progress Series. DOI: 10.3354/meps038201.

Keay J, Bridgham JT, Thornton JW. 2006. The Octopus vulgaris estrogen receptor is a constitutive transcriptional activator: Evolutionary and functional implications. Endocrinology. DOI: 10.1210/en.2006-0363.

Kellis JT, Vickery LE. 1987. The active site of aromatase cytochrome P-450. Differential effects of cyanide provide evidence for proximity of heme-iron and carbon-19 in the enzyme-substrate complex. The Journal of biological chemistry 262:8840-8844

Ketata I, Denier X, Hamza-Chaffai A, Minier C. 2008. Endocrine-related reproductive effects in molluscs. Comparative Biochemistry and Physiology Part C: Toxicology \& Pharmacology 147:261-270 DOI: 10.1016/j.cbpc.2007.11.007.

Lavado R, Janer G, Porte C. 2006. Steroid levels and steroid metabolism in the Mussel Mytilus edulis: The modulating effect of dispersed crude oil and alkylphenols. Aquatic Toxicology 78:S65-S72 DOI: 10.1016/j.aquatox.2006.02.018.

Li Q, Osada M, Suzuki T, Mori K. 1998. Changes in vitellin during oogenesis and effect of estradiol-17 $\beta$ on vitellogenesis in the pacific oyster crassostrea gigas. Invertebrate Reproduction and Development 33:87-93 DOI: 10.1080/07924259.1998.9652345.

Liu W, Li Q, Kong L. 2008. Estradiol-17ß and testosterone levels in the cockle Fulvia mutica during the annual reproductive cycle. New Zealand Journal of Marine and Freshwater Research. DOI: 10.1080/00288330809509970.

Loose DS, Kan PB, Hirst MA, Marcus RA, Feldman D. 1983. Ketoconazole blocks adrenal steroidogenesis by inhibiting cytochrome P450-dependent enzymes. The Journal of clinical investigation 71:1495-1499 DOI: 10.1172/JCI110903.

Lowry OH, Rosebrough NJ, Farr AL, Randall RJ. 1951. Protein measurement with the Folin phenol reagent. The Journal of biological chemistry 193:265-275.

Manolakou P, Lavranos G, Angelopoulou R. 2006. Molecular patterns of sex determination in the animal kingdom: a comparative study of the biology of reproduction. Reproductive Biology and Endocrinology 4:59 DOI: 10.1186/14777827-4-59.

Markov G V., Tavares R, Dauphin-Villemant C, Demeneix BA, Baker ME, Laudet V. 2009. Independent elaboration of steroid hormone signaling pathways in 
789

790

791

792

793

794

795

796

797

798

799

800

801

802

803

804

805

806

metazoans. Proceedings of the National Academy of Sciences 106:11913-11918 DOI: $10.1073 /$ pnas.0812138106.

Matsumoto T, Nakamura AM, Mori K, Akiyama I, Hirose H, Takahashi Y. 2007. Oyster estrogen receptor: cDNA cloning and immunolocalization. General and Comparative Endocrinology 151:195-201 DOI: 10.1016/j.ygcen.2007.01.016.

Meigs RA, Moorthy KB. 1984. The support of steroid aromatization by mitochondrial metabolic activities of the human placenta. Journal of steroid biochemistry 20:883886

Mezghani-Chaari S, Machreki-Ajimi M, Hamza-Chaffai A, Minier C. 2017. High estradiol exposure disrupts the reproductive cycle of the clam Ruditapes decussatus in a sex-specific way. Environmental Science and Pollution Research 24:26670-26680 DOI: $10.1007 / \mathrm{s} 11356-017-0146-4$.

Milczarek R, Sokołowska E, Hallmann A, Kaletha K, Klimek J. 2008. NADPH- and irondependent lipid peroxidation inhibit aromatase activity in human placental microsomes. The Journal of steroid biochemistry and molecular biology 110:230235 DOI: 10.1016/j.jsbmb.2007.11.004.

Miller WL. 2011. Role of Mitochondria in Steroidogenesis. In: Endocrine development. 1-19. DOI: 10.1159/000321204.

Morthorst JE, Holbech H, Jeppesen M, Kinnberg KL, Pedersen KL, Bjerregaard P. 2014. Evaluation of yolk protein levels as estrogenic biomarker in bivalves; comparison of the alkali-labile phosphate method (ALP) and a species-specific immunoassay (ELISA). Comparative Biochemistry and Physiology Part C: Toxicology \& Pharmacology 166:88-95 DOI: 10.1016/j.cbpc.2014.07.008.

Nagai K, Miyamori I, Ikeda M, Koshida H, Takeda R, Suhara K, Katagiri M. 1986. Effect of ketoconazole (an imidazole antimycotic agent) and other inhibitors of steroidogenesis on cytochrome P450-catalyzed reactions. Journal of steroid biochemistry 24:321-323

Newell RIE, Hilbish TJ, Koehn RK, Newell CJ. 1982. Temporal variation in the reproductive cycle of Mytilus edulis L. (Bivalvia, Mytilidae) from localities on the east coast of the United States ( Long Island, New York). Biological Bulletin. DOI: $10.2307 / 1540985$.

Numazawa M, Yoshimura A, Oshibe M. 1998. Enzymic aromatization of 6-alkylsubstituted androgens, potent competitive and mechanism-based inhibitors of aromatase. The Biochemical journal 329 ( Pt 1):151-156

Orlando EF, Davis WP, Guillette LJ. 2002. Aromatase activity in the ovary and brain of the eastern mosquitofish (Gambusia holbrooki) exposed to paper mill effluent. Environmental health perspectives 110 Suppl 3:429-433

Osawa Y, Yoshida N, Fronckowiak M, Kitawaki J. 1987. Immunoaffinity purification of 
807

808

809

810

811

812

813

814

815

816

817

818

819

820

821

822

823

824

825

826

827

828

829

830

831

832

833

834

835

836

837

838

839

840

841

842

843

844

aromatase cytochrome P-450 from human placental microsomes, metabolic switching from aromatization to 1 beta and 2 beta-monohydroxylation, and recognition of aromatase isozymes. Steroids 50:11-28

Passamonti M, Ghiselli F. 2009. Doubly Uniparental Inheritance: Two mitochondrial genomes, one precious model for organelle DNA inheritance and evolution. DNA and Cell Biology. DOI: 10.3238/arztebl.2015.0730.

Peck MR, Labadie P, Minier C, Hill EM. 2007. Profiles of environmental and endogenous estrogens in the zebra mussel Dreissena polymorpha. Chemosphere. DOI: 10.1016/j.chemosphere.2007.04.082.

Puinean AM, Labadie P, Hill EM, Osada M, Kishida M, Nakao R, Novillo A, Callard IP, Rotchell JM. 2006. Laboratory exposure to 17beta-estradiol fails to induce vitellogenin and estrogen receptor gene expression in the marine invertebrate Mytilus edulis. Aquatic toxicology (Amsterdam, Netherlands) 79:376-383 DOI: 10.1016/j.aquatox.2006.07.006.

Puinean AM, Rotchell JM. 2006. Vitellogenin gene expression as a biomarker of endocrine disruption in the invertebrate, Mytilus edulis. Marine Environmental Research. DOI: 10.1016/j.marenvres.2006.04.035.

Ramalho-Santos J, Amaral S. 2013. Mitochondria and mammalian reproduction. Molecular and Cellular Endocrinology 379:74-84 DOI: 10.1016/j.mce.2013.06.005.

Rougée LRA, Richmond RH, Collier AC. 2015. Molecular reproductive characteristics of the reef coral Pocillopora damicornis. Comparative Biochemistry and Physiology Part A: Molecular \& Integrative Physiology 189:38-44 DOI: 10.1016/j.cbpa.2015.07.012.

Santen RJ, Van den Bossche H, Symoens J, Brugmans J, Decoster R. 1983. Site of action of low dose ketoconazole on androgen biosynthesis in men. The Journal of Clinical Endocrinology \& Metabolism 57:732-736 DOI: 10.1210/jcem-57-4-732.

Schwarz TI, Katsiadaki I, Maskrey BH, Scott AP. 2017a. Mussels (Mytilus spp.) display an ability for rapid and high capacity uptake of the vertebrate steroid, estradiol-17 $\beta$ from water. The Journal of steroid biochemistry and molecular biology 165:407-420 DOI: 10.1016/j.jsbmb.2016.08.007.

Schwarz TI, Katsiadaki I, Maskrey BH, Scott AP. 2017b. Rapid uptake, biotransformation, esterification and lack of depuration of testosterone and its metabolites by the common mussel, Mytilus spp. The Journal of steroid biochemistry and molecular biology 171:54-65 DOI: 10.1016/j.jsbmb.2017.02.016.

Schwarz TI, Katsiadaki I, Maskrey BH, Scott AP. 2018. Uptake and metabolism of water-borne progesterone by the mussel, Mytilus spp. (Mollusca). The Journal of steroid biochemistry and molecular biology 178:13-21 DOI: 10.1016/j.jsbmb.2017.10.016. 
Scott AP. 2012. Do mollusks use vertebrate sex steroids as reproductive hormones? Part I: Critical appraisal of the evidence for the presence, biosynthesis and uptake of steroids. Steroids 77:1450-1468 DOI: 10.1016/j.steroids.2012.08.009.

Scott AP. 2013. Do mollusks use vertebrate sex steroids as reproductive hormones? II. Critical review of the evidence that steroids have biological effects. Steroids 78:268-281 DOI: 10.1016/j.steroids.2012.11.006.

Scott AP. 2018. Is there any value in measuring vertebrate steroids in invertebrates? General and Comparative Endocrinology 265: 77-82 DOI: 10.1016/j.ygcen.2018.04.005

Shimizu Y, Yarborough CP, Elger W, Chwalisz K, Osawa Y. 1995. Inhibition of aromatase activity in human placental microsomes by 13-retro-antiprogestins. Steroids 60:234-238

Simoncini T, Genazzani AR. 2003. Non-genomic actions of sex steroid hormones. European journal of endocrinology 148:281-292

Simpson ER, Clyne C, Rubin G, Boon WC, Robertson K, Britt K, Speed C, Jones M. 2002. Aromatase-a brief overview. Annual Review of Physiology 64:93-127. DOI: 10.1146/annurev.physiol.64.081601.142703.

Smith CA, McClive PJ, Western PS, Reed KJ, Sinclair AH. 1999. Conservation of a sexdetermining gene. Nature 402:601-602 DOI: 10.1038/45127.

Smolarz K, Zabrzańska S, Konieczna L, Hallmann A. 2018. Changes in steroid profiles of the blue mussel Mytilus trossulus as a function of season, stage of gametogenesis, sex, tissue and mussel bed depth. General and Comparative Endocrinology 259:231-239 DOI: 10.1016/j.ygcen.2017.12.006.

Stefano GB, Cadet P, Mantione K, Cho JJ, Jones D, Zhu W. 2003. Estrogen signaling at the cell surface coupled to nitric oxide release in Mytilus edulis nervous system. Endocrinology 144:1234-1240 DOI: 10.1210/en.2002-220967.

Thitiphuree T, Nagasawa K, Osada M. 2019. Molecular identification of steroidogenesisrelated genes in scallops and their potential roles in gametogenesis. The Journal of steroid biochemistry and molecular biology 186:22-33 DOI: 10.1093/molbev/msh200.

Thompson EA, Siiteri PK. 1974. Utilization of oxygen and reduced nicotinamide adenine dinucleotide phosphate by human placental microsomes during aromatization of androstenedione. The Journal of biological chemistry 249:5364-5372

Thornton JW, Need E, Crews D. 2003. Resurrecting the ancestral steroid receptor: ancient origin of estrogen signaling. Science 301:1714-1717 DOI: 10.1126/science.1086185.

Tinwell H, Rascle JB, Colombel S, Al Khansa I, Freyberger A, Bars R. 2011. A novel method for measuring aromatase activity in tissue samples by determining estradiol 
concentrations. Journal of Applied Toxicology 31:446-454 DOI: 10.1002/jat.1623.

884

885

886

887

888

889

890

891

892

893

894

895

896

897

898

899

900

901

902

903

904

905

906

907

908

909

910

911

912

913
Tran TKA, MacFarlane GR, Kong RYC, O'Connor WA, Yu RMK. 2016. Potential mechanisms underlying estrogen-induced expression of the molluscan estrogen receptor (ER) gene. Aquatic Toxicology 179:82-94 DOI: 10.1016/j.aquatox.2016.08.015.

Van Tyle JH. 1984. Ketoconazole. Mechanism of action, spectrum of activity, pharmacokinetics, drug interactions, adverse reactions and therapeutic use. Pharmacotherapy. DOI: 10.1002/j.1875-9114.1984.tb03398.x.

Vanhaecke L, Vanden Bussche J, Wille K, Bekaert K, De Brabander HF. 2011. Ultrahigh performance liquid chromatography-tandem mass spectrometry in highthroughput confirmation and quantification of 34 anabolic steroids in bovine muscle. Analytica chimica acta 700:70-77 DOI: 10.1016/j.aca.2010.10.006.

Wang C, Croll RP. 2007. Estrogen binding sites in the sea scallop: Characterization and possible involvement in reproductive regulation. Comparative Biochemistry and Physiology Part B: Biochemistry and Molecular Biology 148:303-313 DOI: 10.1016/j.cbpb.2007.06.008.

Yan H, Li Q, Liu W, Ke Q, Yu R, Kong L. 2011. Seasonal changes of oestradiol-17 $\beta$ and testosterone concentrations in the gonad of the razor clam Sinonovacula constricta (Lamarck, 1818). Journal of Molluscan Studies 77:116-122 DOI: 10.1093/mollus/eyq045.

Yoshida N, Osawa Y. 1991. Purification of human placental aromatase cytochrome P450 with monoclonal antibody and its characterization. Biochemistry 30:3003-3010

Zabrzańska S, Smolarz K, Hallmann A, Konieczna L, Bączek T, Wołowicz M. 2015. Sex-related differences in steroid concentrations in the blue mussel (Mytilus edulis trossulus) from the southern Baltic Sea. Comparative Biochemistry and Physiology Part A: Molecular \& Integrative Physiology 183:14-19 DOI: 10.1016/j.cbpa.2014.12.029.

Zouros E, Oberhauser Ball A, Saavedra C, Freeman KR. 1994. An unusual type of mitochondrial DNA inheritance in the blue mussel Mytilus. Proceedings of the National Academy of Sciences. DOI: 10.1073/pnas.91.16.7463. 
Figure 1

Identification of ${ }^{13} \mathrm{C}_{3}$-labelled steroids by LC-MS/MS.

Positive ion chromatogram of steroid standards (A) was compared to chromatogram obtained from extract of $M$. trossulus exposed to Testosterone-2,3,4- ${ }^{13} \mathrm{C}_{3}$ over $24 \mathrm{~h}$ (B). Abbreviations:

D: Dexamethasone (internal standard), A- ${ }^{13} \mathrm{C}_{3}$ : 4-Androstene-3,17-dione-2,3,4- ${ }^{13} \mathrm{C}_{3}, \mathrm{~T}_{-}{ }^{13} \mathrm{C}_{3}$ : Testosterone-2,3,4- ${ }^{13} \mathrm{C}_{3}$, E1- $-{ }^{13} \mathrm{C}_{3}$ : Estrone-2,3,4- ${ }^{13} \mathrm{C}_{3}, 17 \beta \mathrm{E} 2-{ }^{13} \mathrm{C}_{3}: 17 \beta$-estradiol-2, 3, $4-{ }^{13} \mathrm{C}_{3}$. 

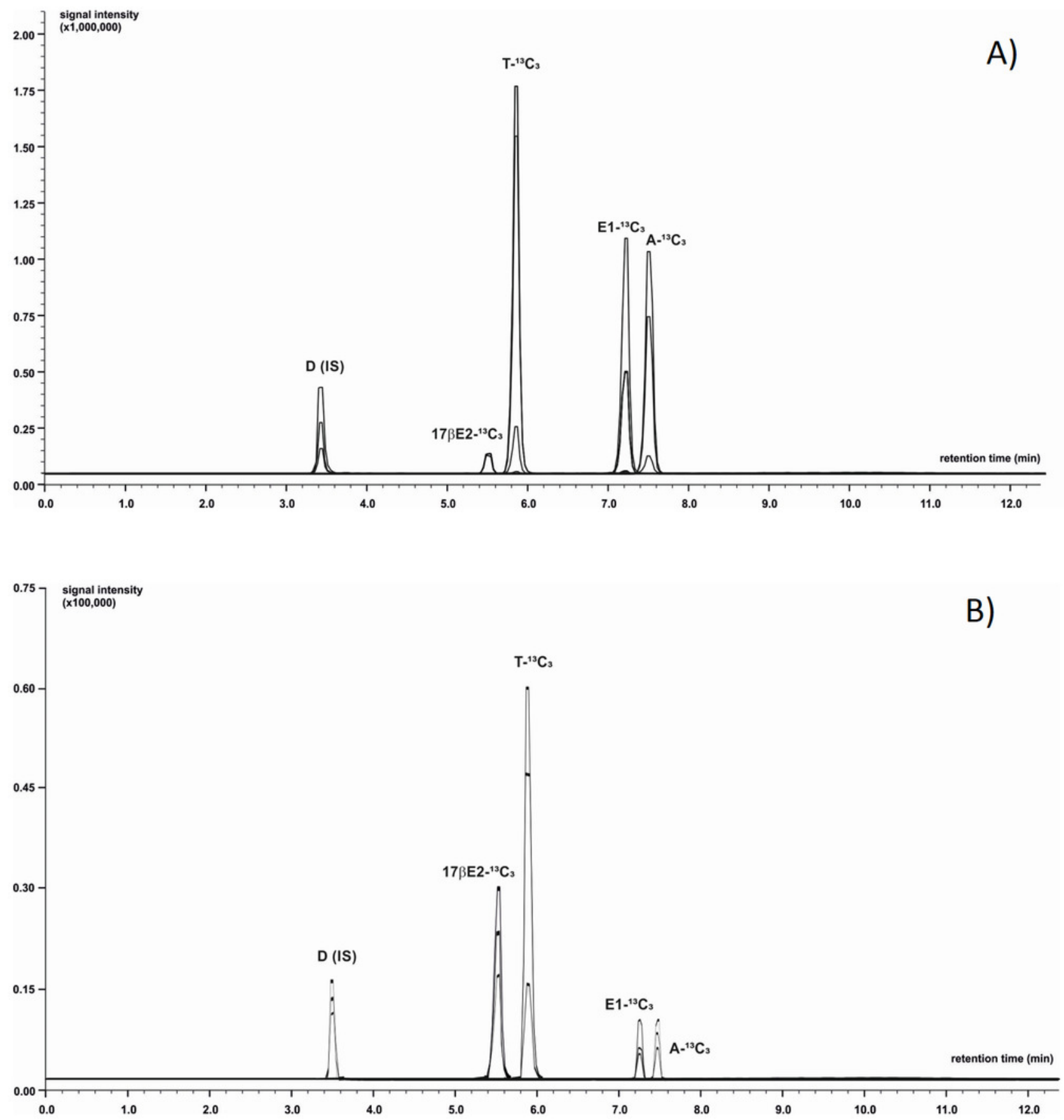
Figure 2

Aromatization efficiency in microsomal fraction isolated from gills (black column) and gonads (grey column) of $M$. trossulus A) temperature dependent efficiency, B) pH dependent efficiency.

Data presented as mean \pm SD $(n=5)$. 

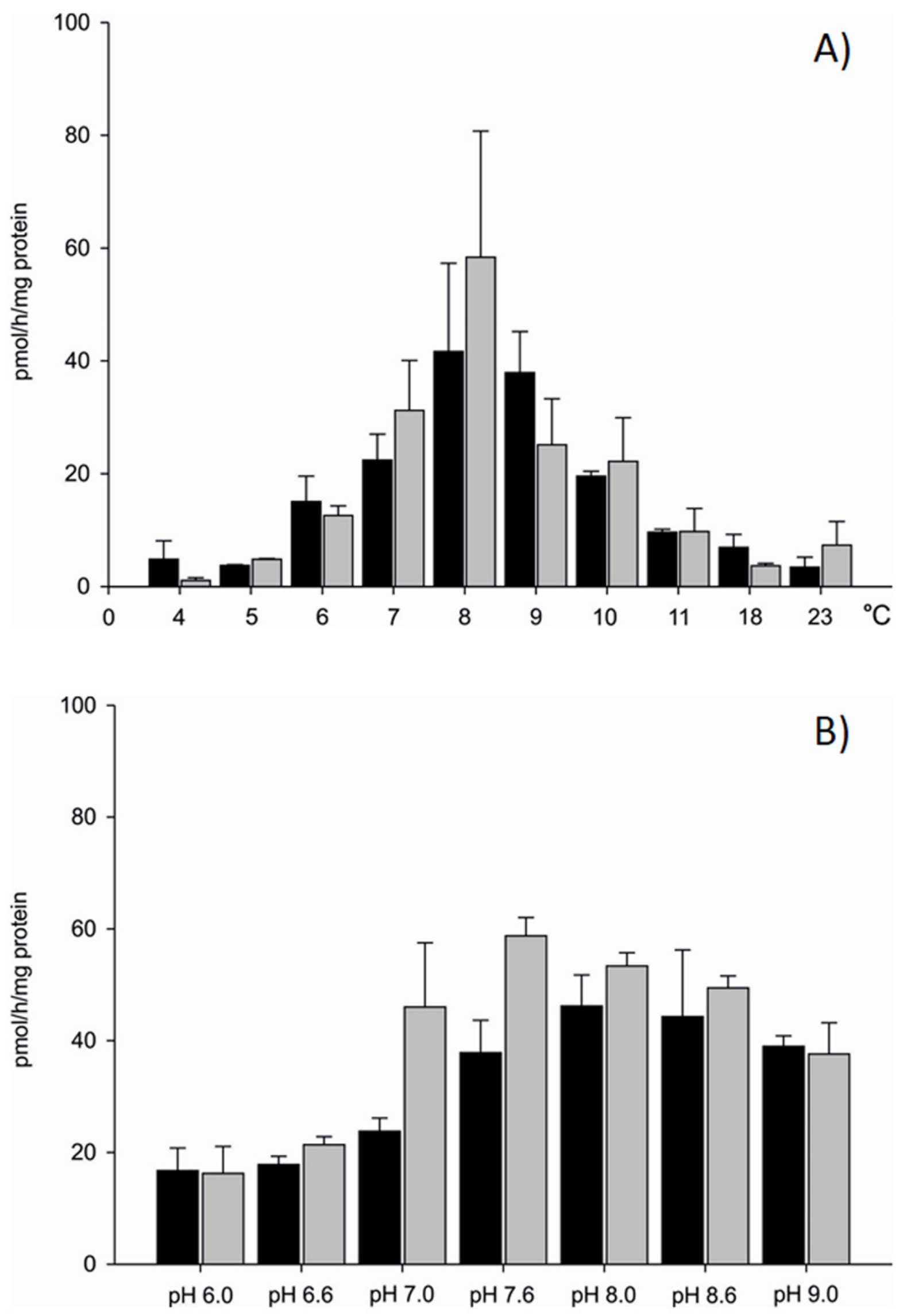


\section{Figure 3}

Seasonal differences in AE in microsomes isolated from gills (black column) and gonads (grey column) of M. trossulus.

Data presented as mean $\pm S D(n=3)$. Significant differences with respect to the "May 2012" groups indicated by ${ }^{* * *} \mathrm{p}<0.05$ (Kruskal-Wallis ANOVA).

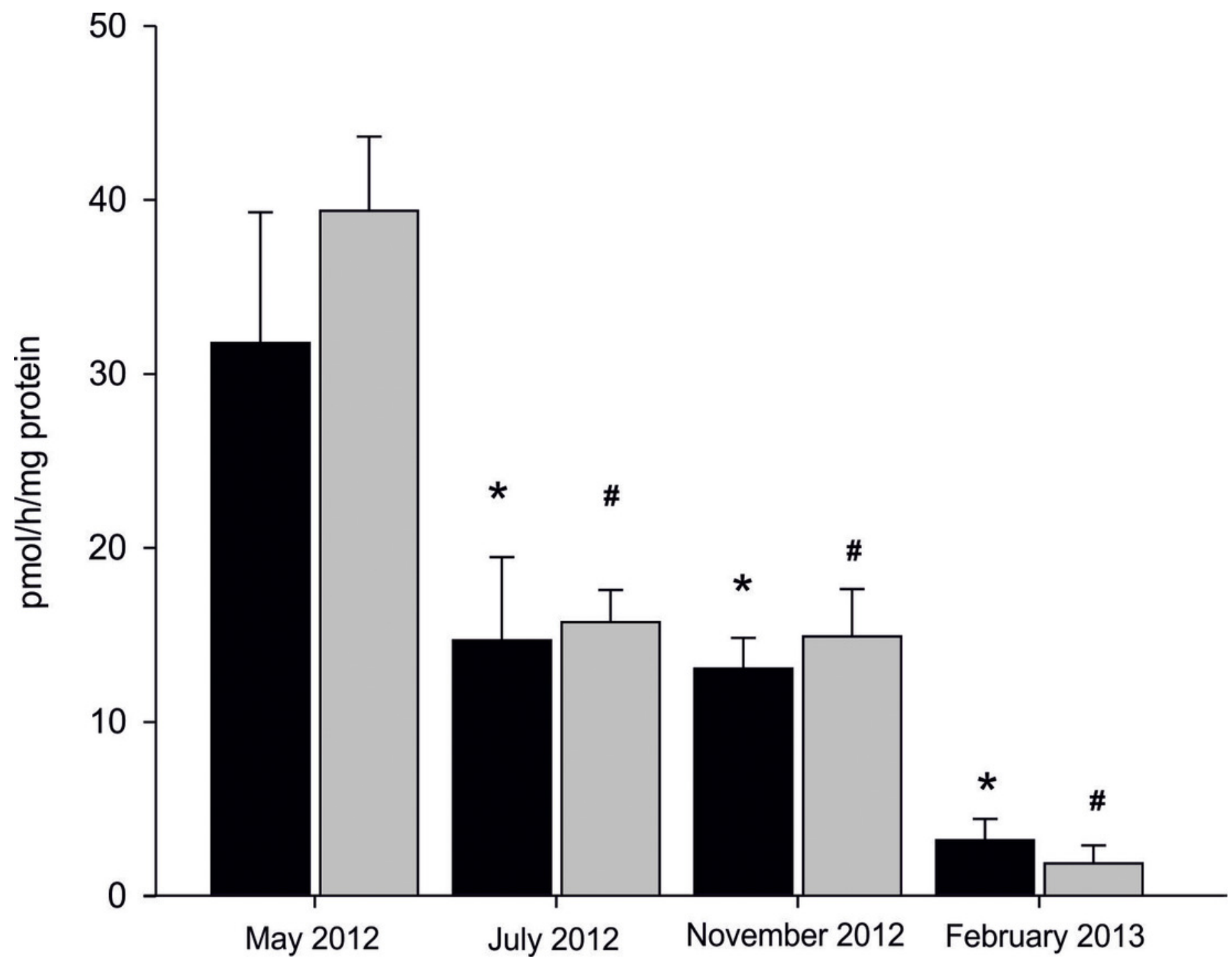


Figure 4

Sex-related aromatization efficiency in microsomes and mitochondria isolated from gills (black column) and gonads (grey column) of M. trossulus.

Data presented as mean \pm SD $(n=3) ; * p<0.05$ compared "gill" and "gonads" groups (Kruskal-Wallis ANOVA), " $p<0.05$ compared "female" and "males" groups (Kruskal-Wallis ANOVA) and " $p<0.05$ compared "microsomes" and "mitochondria" groups (Kruskal-Wallis ANOVA). 


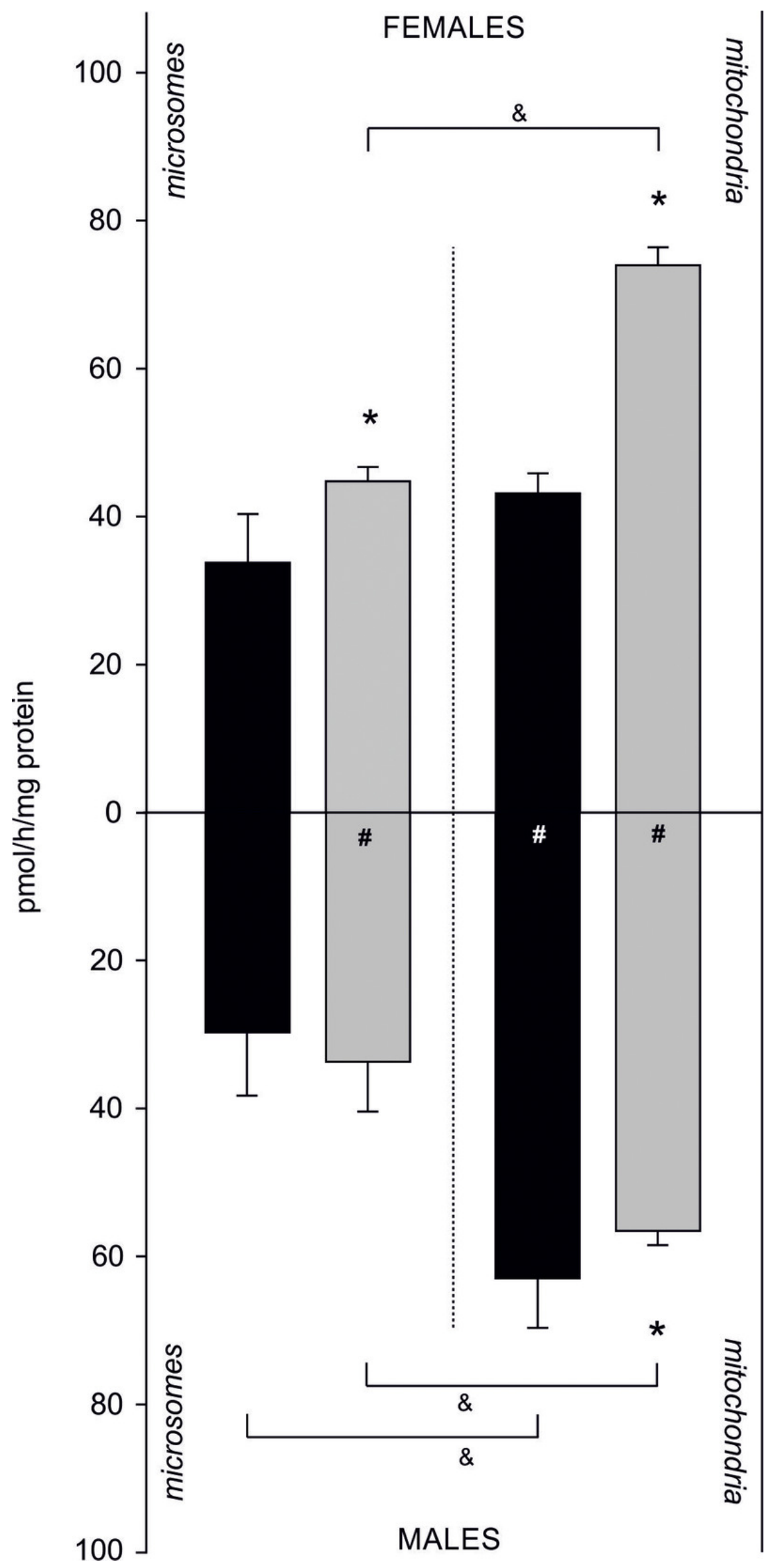

Peer] reviewing PDF | (2019:02:35004:1:1:NEW 26 Mar 2019) 


\section{Figure 5}

Effect of inhibitors on aromatization efficiency in microsomes isolated from gonads of $M$. trossulus.

The effect of letrozole is presented in black column, anastrozole in grey column and ketoconazole in white column. Data presented $A E$ in relation to control (black line marks: $A E$ without inhibitors $=39.04 \pm 7.34 \mathrm{pmol} / \mathrm{h} / \mathrm{mg}$ of protein). Data presented as mean $\pm \mathrm{SD}(\mathrm{n}=$ 3). Significant differences indicated by $* p<0.05$ (Kruskal-Wallis ANOVA). 


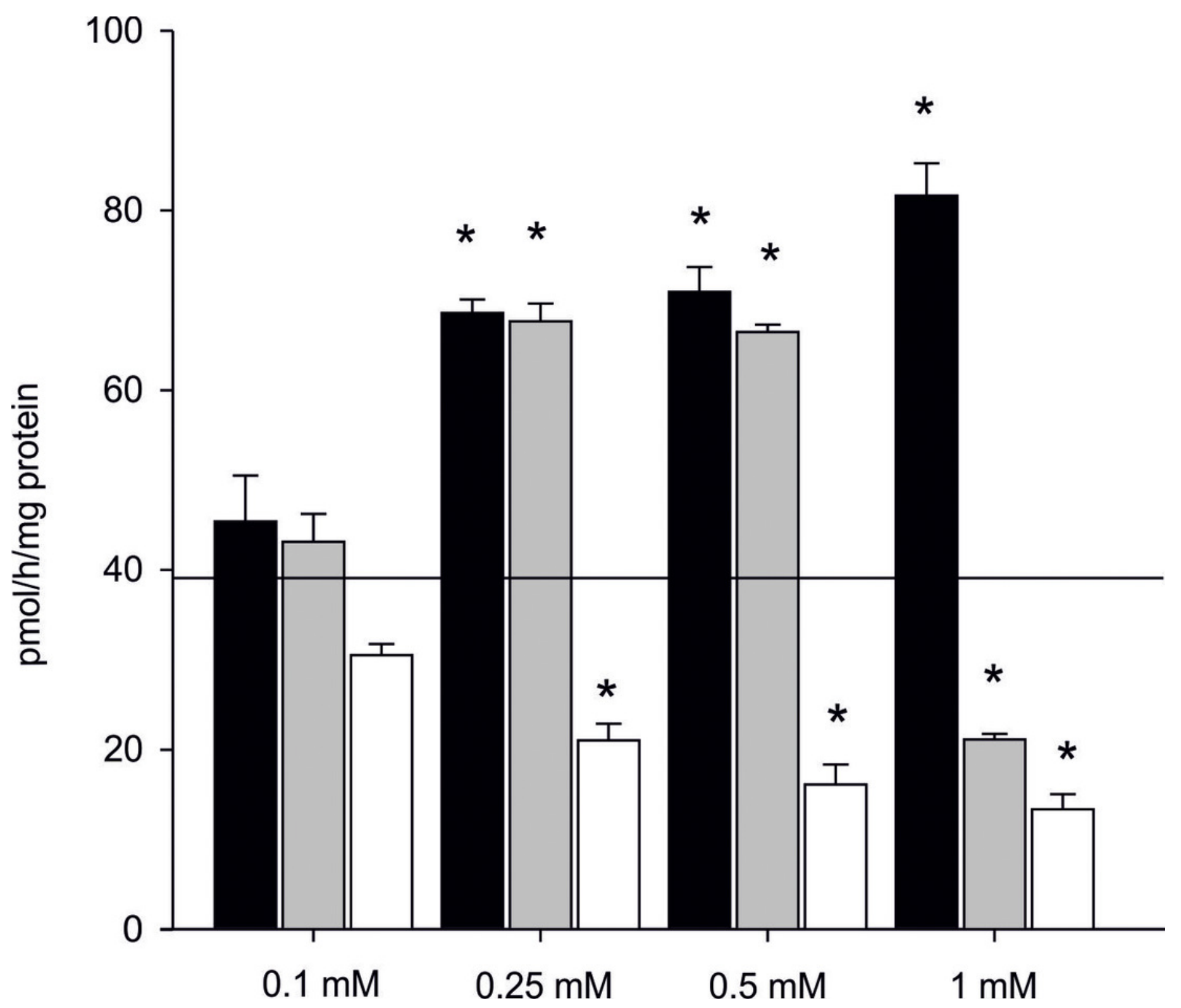


Figure 6

Levels of $\mathrm{A}_{-}{ }^{13} \mathrm{C}_{3}$ : 4-Androstene-3,17-dione-2,3,4- ${ }^{13} \mathrm{C}_{3}, \mathrm{~T}^{13} \mathrm{C}_{3}$ : Testosterone-2,3,4- ${ }^{13} \mathrm{C}_{3}$, E1 $-{ }^{13} \mathrm{C}_{3}$

E1 $-{ }^{13} C_{3}$ Estrone-2,3, $4{ }^{13} C_{3}$ and $17 \beta E 2-{ }^{13} C_{3}: 17 \beta$-estradiol-2,3, $4-{ }^{13} C_{3}$ in $M$. trossulus exposed to 4-Androstene-3,17-dione-2,3,4- ${ }^{13} \mathrm{C}_{3}$ (black column) and Testosterone-2,3,4- ${ }^{13} \mathrm{C}_{3}$ (grey column). Data presented as mean $\pm S D(n=10)$.

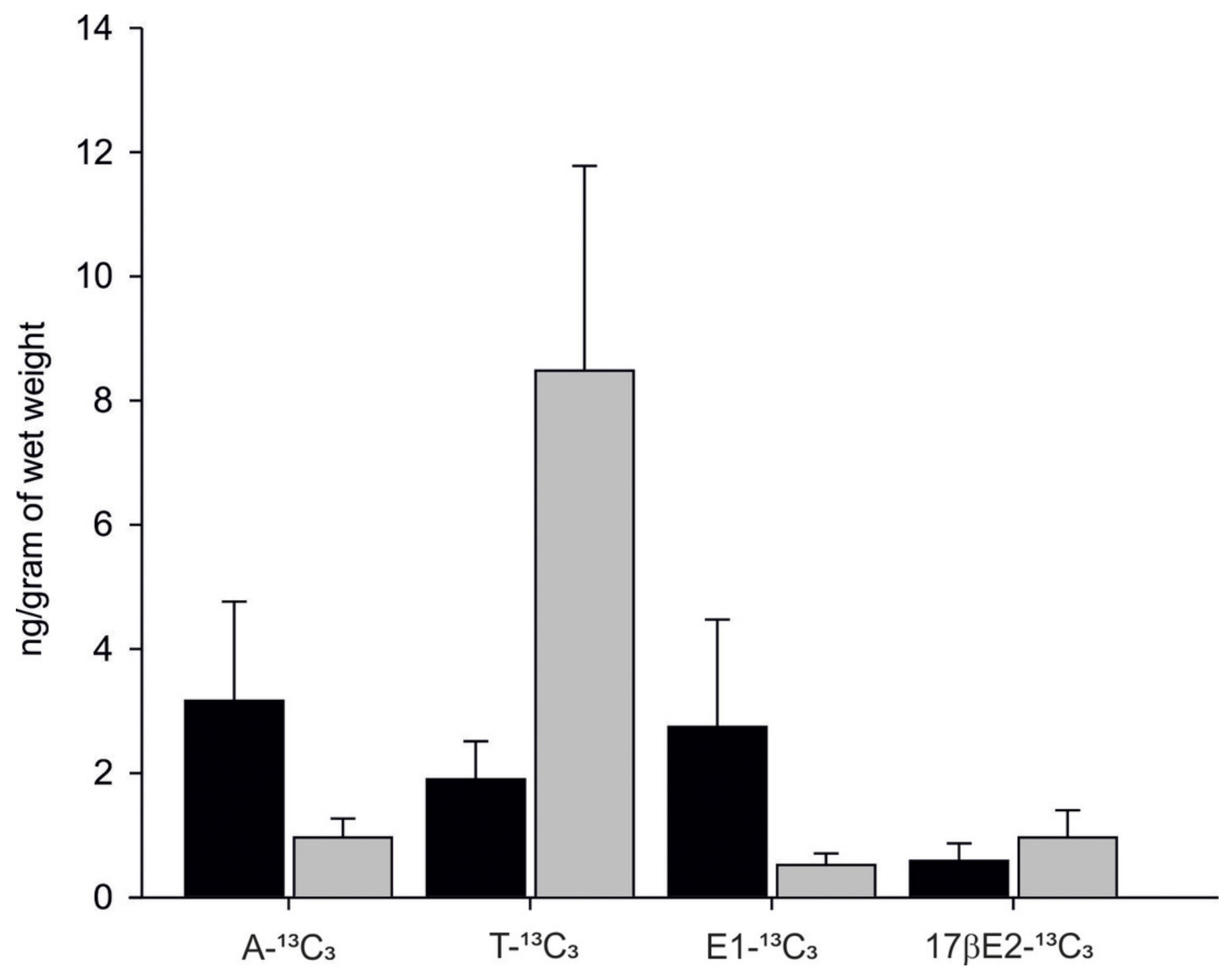




\section{Table $\mathbf{1}$ (on next page)}

Isotopically ${ }^{13} \mathrm{C}_{3}$-labelled standards of steroids.

Dexamethasone (internal standard), 4-Androstene-3,17-dione-2,3,4- ${ }^{13} \mathrm{C}_{3}$,

Testosterone-2,3,4- ${ }^{13} \mathrm{C}_{3}$, Estrone-2,3,4- ${ }^{13} \mathrm{C}_{3}$, $17 \beta$-estradiol-2,3,4- ${ }^{13} \mathrm{C}_{3}$. Detailed data concerning $\mathrm{m} / \mathrm{z}$ values of precursor and product ions for all analyzed steroids. 
2

\begin{tabular}{|c|c|c|c|c|c|}
\hline $\begin{array}{l}\text { Steroid } \\
\text { standards }\end{array}$ & $\begin{array}{l}\text { Molecular } \\
\text { weight }\end{array}$ & $\begin{array}{l}\text { Retention } \\
\text { time }\end{array}$ & $\begin{array}{l}\text { Precursor } \\
\text { ion } \\
\mathrm{m} / \mathrm{z}\end{array}$ & $\begin{array}{l}\text { Product } \\
\text { ion } \\
\mathrm{m} / \mathrm{z}\end{array}$ & $\begin{array}{l}\text { Collision energy } \\
\text { (CE) } \\
{[\mathrm{eV}]}\end{array}$ \\
\hline $\begin{array}{l}\text { Dexamethasone } \\
\text { (internal } \\
\text { standard) }\end{array}$ & 392.46 & 3.51 & 393.10 & $\begin{array}{l}237.15 \\
355.05 \\
373.20\end{array}$ & $\begin{array}{l}-19 \\
-12 \\
-10\end{array}$ \\
\hline $\begin{array}{l}\text { 4-Androstene- } \\
\text { 3,17-dione- } \\
2,3,4-{ }^{13} \mathrm{C}_{3}\end{array}$ & 289.39 & 7.47 & 290.10 & $\begin{array}{l}100.15 \\
272.15 \\
112.15 \\
\end{array}$ & $\begin{array}{l}-22 \\
-16 \\
-25 \\
\end{array}$ \\
\hline $\begin{array}{l}\text { Testosterone- } \\
2,3,4{ }^{-13} C_{3}\end{array}$ & 291.40 & 5.89 & 292.10 & $\begin{array}{l}100.15 \\
112.05 \\
256.30\end{array}$ & $\begin{array}{l}-23 \\
-25 \\
-17\end{array}$ \\
\hline $\begin{array}{l}\text { Estrone-2,3,4- } \\
{ }^{13} \mathrm{C}_{3}\end{array}$ & 273.34 & 7.25 & 274.00 & $\begin{array}{l}256.10 \\
160.05 \\
136.10\end{array}$ & $\begin{array}{l}-14 \\
-18 \\
-22\end{array}$ \\
\hline $\begin{array}{l}17 \beta \text {-estradiol- } \\
2,3,4-{ }^{13} C_{3}\end{array}$ & 275.36 & 5.57 & 258.00 & $\begin{array}{l}163.10 \\
58.15 \\
162.10\end{array}$ & $\begin{array}{l}-19 \\
-24 \\
-18\end{array}$ \\
\hline
\end{tabular}

